\title{
Analysis of a polygeneration plant based on solar energy, dual mode solid oxide cells and desalination
}

\section{Rokni, Masoud}

Published in:

International Journal of Hydrogen Energy

Link to article, DOI:

10.1016/j.ijhydene.2018.03.147

Publication date:

2019

Document Version

Peer reviewed version

Link back to DTU Orbit

Citation (APA):

Rokni, M. (2019). Analysis of a polygeneration plant based on solar energy, dual mode solid oxide cells and desalination. International Journal of Hydrogen Energy, 44(35), 19224-19243.

https://doi.org/10.1016/j.ijhydene.2018.03.147

\section{General rights}

Copyright and moral rights for the publications made accessible in the public portal are retained by the authors and/or other copyright owners and it is a condition of accessing publications that users recognise and abide by the legal requirements associated with these rights.

- Users may download and print one copy of any publication from the public portal for the purpose of private study or research.

- You may not further distribute the material or use it for any profit-making activity or commercial gain

- You may freely distribute the URL identifying the publication in the public portal 
In press in International Journal of Hydrogen Energy.

https://doi.org/10.1016/j.ijhydene.2018.03.147

\title{
Analysis of a Polygeneration Plant based on Solar Energy, Dual Mode Solid Oxide Cells and Desalination
}

Masoud Rokni

\author{
Technical University of Denmark, Mechanical Department, Copenhagen 2800, Denmark \\ MR@mek.dtu.dk
}

\begin{abstract}
Fossil fuels are stored energy during millions of years and we are using it in a rate that new fuels cannot be formed. Renewable energies are not available all the time and there is a need to find ways to store them. One way of storing renewable energies is in fuel form, similar to the fossil fuels and then use this stored fuel whenever needed. The plant design proposed in this paper consists of DishStirling collectors supported by a reversible solid oxide cell acting as a power generator and storage unit, and therefore offering dispatchable power on demand. Further, the system reuses the waste heat for seawater desalination. The present work is an analytical study in which the performance evaluation of a self-sustainable polygeneration system with integrated hydrogen production, power generation, and freshwater production is conducted. An evaluation for selected days, representative for summer, fall, winter and spring in an area with low solar irradiation is studies to investigate the potential of this system to supply $500 \mathrm{~kW}$ continuously and simultaneously producing a considerable amount of freshwater. The study shows that the plant can produced hydrogen even in low irradiation winter days together with at least 6500 liters of freshwater daily.
\end{abstract}

Keywords: Hydrogen; Electrolyze; Solar energy; Reversible solid oxide; Desalination

\section{Introduction}

While energy demand in this fast developing world is increasing, its future is being compromised by the $\mathrm{CO}_{2}$ emissions produced through the burning of fossil fuels and associated global warming. Owing to global warming and its consequences, renewable energy production technologies will be called to play a significant role in the future. Further, it is essential to find a new, effective solutions that allow for the integration of sustainable energy production techniques into the current existing systems and thereby decreasing the emissions. Clean energy technologies are available, but there are still barriers hindering their full integration into the society, the majority of which are economic and social.Energy policies moderate such transitions, and ensure that a specified threshold is met. However, it is desirable that such transitions occur in harmony with the present socioeconomic situations and that they utilize current technological achievements in clean energy production. Furthermore, it is key that these solutions are cost-effective and can be used for polygenerations purposes such as electricity, fuel and freshwater production. In such designs, direct electricity, heat (or cool) and freshwater can be generated from a renewable source such as solar and wind energies, when the source is available.

Electrolysis technology such as solid oxide electrolyte cell (SOEC) can be used to store the excess energy in fuel form when the renewable source exceeds the demand. The stored fuel can then be used to generate power heat/cool and freshwater by solid oxide fuel cell (SOFC) when the demand exceeds the renewable. This implies that there is a need for a reversible solid oxide cell (RSOC) that can produce synthetic fuel from excess electricity, or produce electricity from stored fuel when reversed. [1] showed the feasibility of the concept and successful reversible operation of a dual cell through electrochemical tests carried out by impedance spectroscopy. A recent study demonstrates that such system may not only be feasible but also beneficial as the lifetime of the device increases significantly by decreasing cell degradation [2]. They came to the conclusion that by operating the cell in a simple 
electrolysis mode its microstructure tends to deteriorate in the proximity of the interface between the oxygen electrode and electrolyte layer. But surprisingly if the cell is operated in reversible mode no microstructural damage is observed. In other words, dual mode operation eliminates cell degradation. [3] reviewed technological development of hydrogen production from a SOEC system in terms of materials, cell configuration and electrode depolarizations. [4] studied a reactor combining a SOEC section with a Fischer Tropsch section for methane production and [5] carried out an experimental study to demonstrate the heat spreading capabilities and power limitations of high-temperature applications in SOEC/SOFC stacks.

Solar energy is going to play an important role in the future power plants for multi-generation products. Owing to the common nature of fluctuation in energy (also for other renewable sources), most of renewable based plants need a storage unit. With that, renewable energy plants can provide dispatchable power, enabling stand-alone systems for facilitating the grid operation. Parabolic trough solar water heating is a well-proven solar energy technology that is being used on a commercial scale. High-temperature parabolic trough solar collector (PTSC) systems are currently operating in solar electric generating systems. For example, [6] conducted thermal simulation of a PTSC to estimate the transient performance of a solar industrial water heating system. [7] developed a mathematical model for PTSC and compared the results with experimental data, finding a small percent error. [8] designed and experimentally validated an adsorption icemaker driven by PTSC, and integrated it with a sensible thermal storage tank successfully. [9] experimented on innovative flat aluminum absorbers for process heat and direct steam generation in small PTSC systems. [10] studied a RSOC with photovoltaic (PV) to design a possible future power plant using solar energy that can produce electricity at any time of the day, for example, at night.

Direct contact membrane distillation (DCMD) is a thermal separation process where only the water vapor (or other volatile) passes through a micro-porous hydrophobic membrane while impurities, such as salt, cannot cross the membrane. The vapor pressure gradient created by the temperature difference between both sides of the membrane drives the process. [11] reviewed the desalination of seawater by the DCMD system, and its performance from laboratory scale to pilot projects. [12] showed experimentally that $99.99 \%$ of salt can be separated from hot water at $80^{\circ} \mathrm{C}$ in optimum conditions and with optimum membrane material selection. Desalination powered by solar energy is an attractive solution that can address the worldwide water-shortage problem without contributing significantly to greenhouse gas emissions. It is worth noting that often there is shortage of fresh water where solar radiation is high. As deliberated in [13], a promising system for renewable energy desalination is the utilization of low-temperature DCMD systems. The study by [14] showed that experimental data agreed very well with the calculated results in terms of vapor mass flux, as well as membrane and total heat transfer coefficients. In addition, such a technique has a great advantage because it works at lower temperatures, even down to $40^{\circ} \mathrm{C}(313 \mathrm{~K})$, which allows it to use lower temperatures sources and avoid the great latent heat of water [15].

In this work, a poly-generation system is presented that uses a Dish-Stirling units to convert solar radiation into electricity and drive an RSOC for storing renewable energy source in fuel form. Further, the waste heat is recovered for seawater distillation through a DCMD technique. Such a system will result in a self-sufficient and flexible poly-generation plant driven by solar power only that can be regulated for different output combinations of hydrogen, electricity and freshwater. A complete balance of plant is designed and its performance is analyzed thermodynamically. The plant is then evaluated for selected days in different seasons (summer, fall, winter and spring) accounting for different solar irradiation in low solar energy climate. The present study is completely new and no similar study can be found in the open literature. The objective is thermodynamic analysis and cost estimation is out of the scope of present study.

\section{Plant Overview}

The block diagram in Figure 1 illustrates that the plant delivers power to the grid by converting the solar energy collected by the Dish-Stirling devices. Further, the design supports a RSOC system 
in order to overcome the fluctuating nature of the solar radiation by producing hydrogen when solar energy is low or not available. The idea is that the Dish-Stirling delivers part of its load to the RSOC for storage by producing fuel (hydrogen) during the peak hours of radiation (SOEC mode). Then during low or zero radiation, the RSOC uses the produced and stored fuel to produce power and cover the power demand (SOFC mode). At the same time, the design supports a seawater desalination plant that uses the excess heat to produce freshwater continuously. Furthermore, a parabolic trough solar collector (PTSC) uses the solar energy to generate steam for the system.

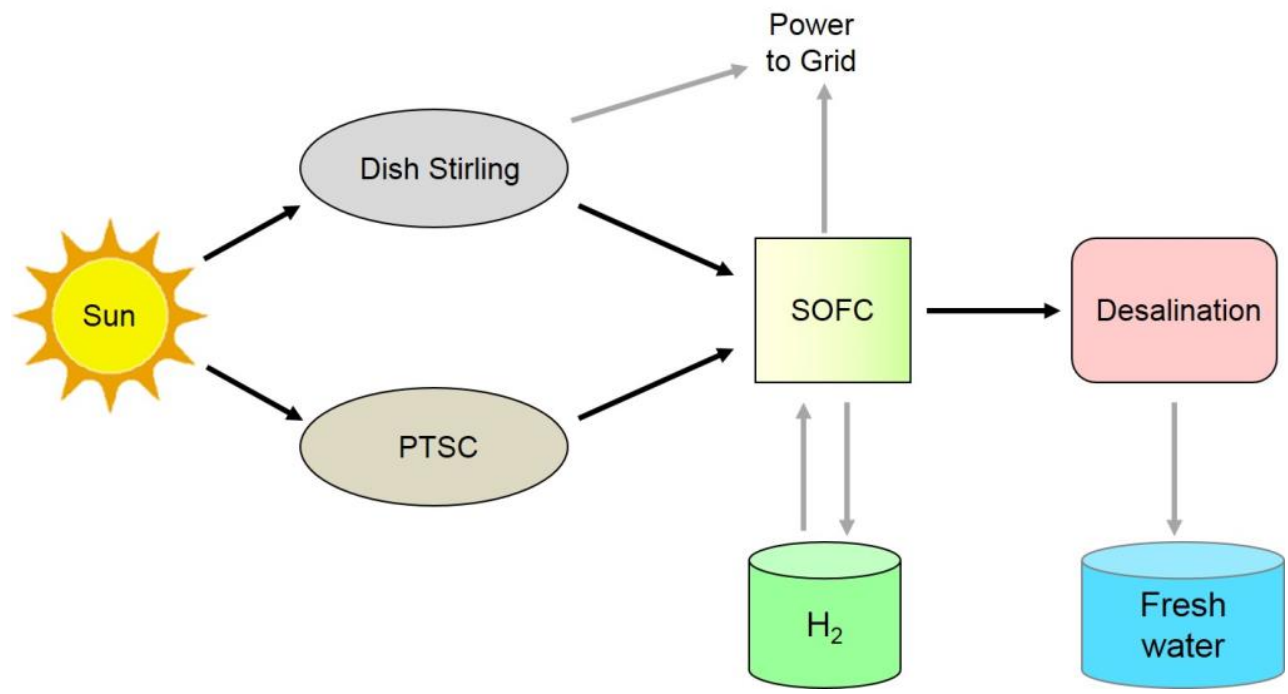

Figure 1. Block diagram representing energy flows in the plant.

It is worth to point out that such plants are rather complex and challenging. One of the challenges would be is the plant price and payback time. The prices for RSOC and DCMD are unknown since they are not commercialized yet. Even though there is a good price approximation for each of them but still they cannot be certain. Political decisions and governmental subsidies will also have a great impact on future price development of such devices [16]. Another challenges is the proper functionality of the RSOC under real condition. Even though their functionality and degradation elimination has experimentally been proved but their practical functionality has not yet been proved.

Before explaining the plant's operation in detail, a description of the models for the main components is provided in the sections that follow.

\section{Methodology and Modelling}

In this study, two different sub-models represent the dual-mode operation of the system namely electrolysis mode (SOEC) and fuel cell mode (SOFC).

\subsection{SOFC Modeling}

A SOFC converts the chemical fuels directly to electrical power by ionizing oxygen and the allowing the oxygen ions to react with the feeding fuel. Heat will also be released though such conversion. The SOFC model used in this study is similar to the previous published and validated model presented in [17]. It is a zero-dimensional model, which calculates the power using a detailed electrochemical model by calibrating the activation, ohmic and concentration losses with experimental data for gas temperatures between $650-800^{\circ} \mathrm{C}(920$ to $1073 \mathrm{~K})$. It also calculates the outlet gases composition based on equilibrium through Gibbs minimization method. Thus the model distinguishes between electrochemical modeling, calculation of cell irreversibility and species compositions at outlet.

For electrochemical modeling, the operational voltage $\left(E_{c e l l}\right)$ found to be 
where $E_{\text {Nernst }}, \Delta E_{a c t}, \Delta E_{\text {ohm }}$, and $\Delta E_{\text {conc }}$ are the Nernst ideal reversible voltage, activation polarization, ohmic polarization, and concentration polarization, respectively. Assuming that only $\mathrm{H}_{2}$ is electrochemically converted, the Nernst equation can be written as,

$$
E_{\text {Nernst }}=\frac{-\Delta g_{\mathrm{f}}{ }^{0}}{n_{\mathrm{e}} F}+\frac{R T}{n_{\mathrm{e}} F} \ln \left(\frac{p_{\mathrm{H}_{2}, \text { tot }} \sqrt{p_{\mathrm{O}_{2}}}}{p_{\mathrm{H}_{2} \mathrm{O}}}\right)
$$

$$
p_{\mathrm{H} 2, \mathrm{tot}}=p_{\mathrm{H} 2}+p_{\mathrm{CO}}+4 p_{\mathrm{CH} 4}
$$

where $\Delta g_{f}^{O}$ is the Gibbs free energy (for $\mathrm{H}_{2}$ reaction) at standard temperature and pressure. The watergas shift reaction is very fast and therefore the assumption that $\mathrm{H}_{2}$ is the only species to be electrochemically converted is justified [18] and [19]. In the above equations, $p_{H 2}$ and $p_{H 2 O}$ are the partial pressures for $\mathrm{H}_{2}$ and $\mathrm{H}_{2} \mathrm{O}$, respectively. It should be noted that the steam reforming and the associated water gas shift reactions are efficiently modeled in the calculations.

The activation polarization can be evaluated using the Butler-Volmer equation [20]. The activation polarization term is isolated from the other polarization terms, to determine the charge transfer coefficients and the exchange current density from the experiments by the curve fitting technique. The activation polarization is expressed by the following equation,

$$
\Delta E_{a c t}=\frac{R T}{(0.001698 T-1.254) F} \sinh ^{-1}\left[\frac{i_{d}}{2\left(13.087 T-1.096 \times 10^{4}\right)}\right],
$$

where $R, T, F$, and $i_{d}$ are the universal gas constant, operating temperature, Faraday constant, and current density, respectively.

The ohmic polarization [21] depends on the electrical conductivity of the electrodes as well as the ionic conductivity of the electrolyte. This is also validated with experimental data for a cell with a specified anode thickness $\left(t_{a n}\right)$, electrolyte thickness $\left(t_{e l}\right)$, and cathode thickness $\left(t_{c a}\right)$. The ohmic polarization is given as follows,

$$
\Delta E_{o h m}=\left(\frac{t_{a n}}{\sigma_{a n}}+\frac{t_{e l}}{\sigma_{e l}}+\frac{t_{c a}}{\sigma_{c a}}\right) i_{d}
$$

where $t_{a n}=600 \mu \mathrm{m}, t_{e l}=50 \mu \mathrm{m}$, and $t_{c a}=10 \mu \mathrm{m} . \sigma_{a n}, \sigma_{e l}$, and $\sigma_{c a}$ are the conductivities of the anode, electrolyte, and cathode, respectively, and may be expressed as follows.

$$
\begin{aligned}
& \sigma_{a n}=10^{5}, \quad \sigma_{c a}=\frac{5.760 \times 10^{7}}{T} \exp \left(-\frac{0.117}{8.617 \times 10^{-5} T}\right) \\
& \sigma_{e l}=8.588 \times 10^{-8} T^{3}-1.101 \times 10^{-4} T^{2}+0.04679 T-6.54
\end{aligned}
$$

The concentration polarization is dominant at high current densities for anode-supported SOFCs, wherein insufficient amounts of reactants are transported to the electrodes and consequently, the voltage is reduced significantly. As in the previous case, the concentration polarization was validated with experimental data by introducing the anode limiting current, [22], in which the anode porosity and tortuosity were considered among other parameters. The concentration polarization is modeled as,

$$
\Delta E_{\text {conc }}=B\left(\ln \left(1+\frac{p_{H_{2} i_{d}}}{p_{H 2 O} i_{a s}}\right)-\ln \left(1-\frac{i_{d}}{i_{a s}}\right)\right)
$$

where $B$ is the diffusion coefficient, which is determined using a calibration technique as 


$$
\mathrm{B}=\left(0.008039 \mathrm{X}_{\mathrm{H} 2}^{-1}-0.007272\right) \frac{T}{T_{r e f}}
$$

185

$T_{r e f}$ is the reference temperature $(1023 \mathrm{~K})$, and the anode limiting current is defined as

$$
i_{a s}=\frac{2 F p_{H 2} D_{b i n} V_{a n}}{R T t_{a n} \tau_{a n}}
$$

where $V_{a n}$ and $\tau_{a n}$ are the porosity (30\%) and tortuosity (2.5) of the anode, respectively. The binary diffusion coefficient is given by

$$
D_{b i n}=\left(-4.107 \times 10^{-5} X_{H 2}+8.704 \times 10^{-5}\right)\left(\frac{T}{T_{r e f}}\right)^{1.75} \frac{p_{r e f}}{p},
$$

which is also calibrated against the experimental data. $p_{\text {ref }}$ is the reference pressure $(1.013 \mathrm{bar})$, and $X_{H_{2}}$ is the mass reaction rate of $\mathrm{H}_{2}$. Lastly, the current density $i_{d}$ is directly proportional to the amount of reacting $\mathrm{H}_{2}$ according to Faraday's law

$$
i_{d}=\frac{\dot{n}_{H 2} 2 F}{A}
$$

where $\dot{n}_{H 2}$ is the molar reaction rate of $\mathrm{H}_{2}$. The area A is a physical property of the cell and was 144 $\mathrm{cm}^{2}$ in this study.

The SOFC model in this study aims at representing the performance of the second generation SOFC stacks developed by Topsoe Fuel Cell A/S (TOFC) and the Fuel Cells and Solid State Chemistry Division at Ris $\varnothing$ - DTU (Technical University of Denmark). This SOFC type is anode supported, with a Ni/YSZ ${ }^{1}$ anode, a YSZ electrolyte, and an $\mathrm{LSM}^{2} / \mathrm{YSZ}_{\text {cathode [23]. }}$

The fuel composition at the anode outlet is calculated using the Gibbs minimization method [24]. Equilibrium at the anode outlet temperature and pressure is assumed for $\mathrm{H}_{2}, \mathrm{CO}, \mathrm{CO}_{2}, \mathrm{H}_{2} \mathrm{O}, \mathrm{CH}_{4}$, and $\mathrm{N}_{2}$. Thus, the Gibbs minimization method calculates the compositions of these species at the outlet by minimizing their Gibbs energy. The equilibrium assumption is reasonable, since the methane content in this study is very low.

In order to calculate the voltage efficiency of the SOFC cells, the power production from the SOFCs $\left(P_{S O F C}\right)$, which depends on the amount of chemical energy fed to the anode, the reversible efficiency $\left(\eta_{r e v}\right)$, the voltage efficiency $\left(\eta_{v}\right)$, and the fuel utilization factor $\left(U_{F}\right)$ is evaluated. It is defined in the mathematical form in equation 18.

$$
P_{S O F C}=\left(\mathrm{LHV}_{\mathrm{H}_{2}} \dot{n}_{\mathrm{H}_{2}, \text { in }}+\mathrm{LHV}_{C O} \dot{n}_{C O, \text { in }}+\mathrm{LHV}_{\mathrm{CH}_{4}} \dot{n}_{\mathrm{CH}_{4}, \text { in }}\right) \eta_{r e v} \eta_{v} U_{F}
$$

where $U_{F}$ is a constant and $\eta_{v}$ is defined as follows.

$$
\eta_{\mathrm{v}}=\frac{\Delta E_{\text {cell }}}{E_{\text {Nernst }}}
$$

Note that the utilization factor in SOFCs can be defined as the amount of $\mathrm{O}_{2}$ consumed, because $\mathrm{O}_{2}$ ions are the carriers. The reversible efficiency is the maximum possible efficiency, which is defined as the relationship between the maximum electrical energy available (change in Gibbs free energy) and the LHV (lower heating value) of the fuels, as shown below [25].

$$
\eta_{\text {rev }}=\frac{\left(\Delta \bar{g}_{f}\right)_{\text {fuel }}}{\mathrm{LHV}_{\text {fuel }}}
$$

\footnotetext{
${ }^{1}$ Yttria-stabilized zirconia.

${ }^{2}$ Lanthanum strontium manganite.
} 


$$
\begin{aligned}
\left(\Delta \bar{g}_{f}\right)_{\text {fuel }} & =\left[\left(\bar{g}_{f}\right)_{\mathrm{H}_{2} \mathrm{O}}-\left(\bar{g}_{f}\right)_{\mathrm{H}_{2}}-\frac{1}{2}\left(\bar{g}_{f}\right)_{\mathrm{O}_{2}}\right] y_{\mathrm{H}_{2}, \text { in }} \\
& +\left[\left(\bar{g}_{f}\right)_{\mathrm{CO}_{2}}-\left(\bar{g}_{f}\right)_{\mathrm{CO}}-\frac{1}{2}\left(\bar{g}_{f}\right)_{\mathrm{O}_{2}}\right] y_{\mathrm{CO}, \text { in }} \\
& +\left[\left(\bar{g}_{f}\right)_{\mathrm{CO}_{2}}+2\left(\bar{g}_{f}\right)_{\mathrm{H}_{2} \mathrm{O}}-\left(\bar{g}_{f}\right)_{\mathrm{CH}_{4}}-2\left(\bar{g}_{f}\right)_{\mathrm{O}_{2}}\right] y_{\mathrm{CH}_{4}, \text { in }}
\end{aligned}
$$

where $\Delta \bar{g}$ is the average Gibbs free energy from the inlet to the outlet and $y$ is the mole fraction. The partial pressures are assumed to be the average pressures between the inlet and the outlet.

$$
\begin{aligned}
& \bar{p}_{j}=\left(\frac{y_{j, \text { out }}+y_{j, \text { in }}}{2}\right) \bar{p} \quad j=\left\{\mathrm{H}_{2}, \mathrm{CO}, \mathrm{CH}_{4}, \mathrm{CO}_{2}, \mathrm{H}_{2} \mathrm{O}, \mathrm{N}_{2}\right\} \\
& \bar{p}_{\mathrm{O}_{2}}=\left(\frac{y_{\mathrm{O}_{2}, \text { out }}+y_{\mathrm{O}_{2}, \text { in }}}{2}\right) \bar{p}_{\mathrm{c}}
\end{aligned}
$$

Additionally, equations for conservation of mass (with molar flows), conservation of energy, and conservation of momentum were also included in the model. Table 1 displays the main parameters for the SOFC stacks used in this study.

Table 1. The main SOFC parameters used in this study.

\begin{tabular}{l|c}
\hline \multicolumn{1}{c|}{ Parameter } & Value \\
\hline Fuel utilization factor & 0.8 \\
Number of cells in stack & 70 \\
Number of stacks & 200 \\
Anode pressure drop ratio (bar) & 0.01 \\
Cathode pressure drop ratio (bar) & 0.05 \\
Outlet temperatures $\left({ }^{\circ} \mathrm{C}\right)$ & 750 \\
\hline
\end{tabular}

\subsection{SOEC Modeling}

Reversing the operation mode of a SOFC results in an electrolysis operation, by applying electrical power and then splitting steam into oxygen and hydrogen molecules. The model used in this study is based on the model presented by [26], which also contain a detailed electrochemical model, and captures the experimental data very well. Here, the Nernst potential which gives the theoretical minimum electrical work, will be added with ohmic, activation, and concentration polarizations [27].

The Butler-Volmer equation determines the activation over-potential considering that both cathodic and anodic reaction occur on the same electrode. The ohmic over-potential is directly to the current density, electrolyte thickness and the operating temperature. The concentration over-potential is dominant at high current densities wherein insufficient amounts of reactants are transported to the electrodes (with respect to the current density) and thereby the voltage reduces significantly [17].

Note that the energy applied through electrical work might not be enough to drive the system's unspontaneous reactions. The remaining energy is then applied by a heat source at higher temperature and/or by directly increasing the power (increasing the current through the cells), which in turn produces more heat owing to the Joule effect.

The power, the voltage and the current are dependent on each other and therefore, if one of them is defined, then the others can be determined. Another way of defining these parameters would be by fixing the $\mathrm{H}_{2}$ production or fixing the molar fraction at the outlet.

Then, the cell voltage and the current density are calculated using the power input.

$$
P_{\text {SOFC }}=N_{\text {satck }} N_{\text {cell }} E_{\text {cell }} A_{\text {cell }} J
$$

where $N_{\text {stack }}, N_{\text {cdll }}, E_{\text {cell }}, A_{\text {cell }}$ and $J$ are the number of stacks, number of cells per stack, cell voltage, single cell area and current density, respectively. The Nernst potential gives the theoretical minimum 
electrical work, but in reality, part of the voltage is lost irreversibly owing to polarizations such as ohmic, activation, and concentration polarizations. The ohmic resistance remains constant while the other two vary depending on the current applied, i.e., ohmic polarization increases proportionally with the current, while activation polarization and concentration polarization are dominant at low and high current levels, respectively [17]. Thus, the minimum electrical work that has to be applied to the SOEC is determined by the Nernst potential plus the polarization losses. The cell voltage is defined by determining the Nernst voltages $\left(E_{\text {Nernst }}\right)$ as follows:

$$
E_{\text {cell }}=E_{\text {Nernst }}+\Delta E_{\text {act }}+\Delta E_{\text {ohm }}+\Delta E_{\text {conc }}
$$

The Nernst potential and the polarizations in the SOEC (activation, ohmic and concentration) are calculated as explained in [17]. The diffusion coefficient is approximated using the kinetic theory and the Chapman-Enskog theory [27].

Note that the energy applied through electrical work might not be enough to drive the system's unspontaneous reactions. The remaining energy is then applied by a heat source at higher temperature and/or by directly increasing the power (increasing the current through the cells), which in turn produces more heat owing to the Joule effect [28]. When the heat produced equals the heat demand in the reaction (thermo-neutral point), then the voltage becomes

$$
E_{t h n}=\frac{\Delta_{r} H}{2 F}
$$

where $\Delta_{r} H$ is the enthalpy change in the reactions, and $F$ is the Faraday constant $(96485.34 \mathrm{C} / \mathrm{mol})$.

The outlet concentrations and mass flows can be determined by molar balance of each element and using the current density to determine the quantity of reactions taking place. The molar production of $\mathrm{H}_{2}$ (or moles of $\mathrm{H}_{2} \mathrm{O}$ molecules split) is fixed for a certain current value; consequently, $\mathrm{O}_{2}$ is produced according to the reaction

$$
\begin{aligned}
& \dot{m}_{\text {out }}^{H 2}=\frac{N_{\text {stack }} N_{\text {cell }} A_{\text {cell }} J}{2 F} \\
& \dot{m}_{\text {out }}^{H 2 O}=\dot{m}_{\text {in }}^{H 2 O}-\dot{m}_{\text {split }}^{H 2 O}=\dot{m}_{\text {in }}^{H 2 O}-\frac{N_{\text {stack }} N_{\text {cell }} A_{\text {cell }} J}{2 F} \\
& \dot{m}_{\text {out }}^{O 2}=\dot{m}_{\text {in }}^{O 2}-\frac{\dot{m}_{\text {split }}^{H 2 O}}{2}=\dot{m}_{\text {in }}^{O 2}-\frac{N_{\text {stack }} N_{\text {cell }} A_{\text {cell }} J}{2 \times 2 F}
\end{aligned}
$$

Note that the power, the voltage and the current are dependent on each other; therefore, if one of them is defined, the others can be determined. Another way of defining these parameters would be by fixing the $\mathrm{H}_{2}$ production or fixing the molar fraction at the outlet.

Finally, the efficiency is defined as

$$
\eta_{\text {SOEC }}=\frac{L H V \cdot \dot{m}_{H 2, \text { prodcution }}}{P O W E R+Q_{\text {in }}}
$$

where $P O W E R$ and $Q_{\text {in }}$ are the electrical power required to run the electrolyzer and the heat input required to preheat the water, while $\dot{m}_{H 2 \text {,prodcution }}$ is the mass flow rate of hydrogen production. Table 2 illustrates the main parameters for the SOEC component.

Table 2. Specifications for SOEC (anode and cathode referred to fuel cell mode).

\begin{tabular}{l|l}
\hline \multicolumn{1}{c|}{ Parameter } & \multicolumn{1}{c}{ Value } \\
\hline Anode thickness & $600 \mu \mathrm{m}$ (Nickel and Yttria Stabilized Zirconia cermet) \\
\hline Cathode thickness & $50 \mu \mathrm{m}$ (Strontium-doped lanthanum manganite) \\
\hline Electrolyte thickness & $10 \mu \mathrm{m}($ Yttria Stabilized Zirconia) \\
\hline Cell area & $144 \mathrm{~cm}^{2}(12 \mathrm{~cm} \times 12 \mathrm{~cm})$ \\
\hline Number of cells per stack & 70 \\
\hline Number of stacks & 200 \\
\hline
\end{tabular}




\begin{tabular}{l|l}
\hline Operating temperature & $750^{\circ} \mathrm{C}$ \\
\hline Porosity & $30 \%$ \\
\hline Tortuosity & 2.5 \\
\hline
\end{tabular}

The reason why different modeling for the SOFC and SOEC are used here is due to the fact that the current SOEC model has been validated in the literature.

[29] and [26] discussed the validity of the model with experimental data in terms of energy efficiency and $\mathrm{H}_{2} \mathrm{O}$ conversion for different current densities and at different operating temperatures.

\subsection{Modeling of Dish-Stirling}

This model consists of two different parts: the solar dish collector and the Stirling engine. The Stirling model is adopted from the model presented in [28] and is based on a pseudo-Stirling cycle, which provides better agreement with engine performance data. Stirling engines are noted for their quiet operation and the ease with which they can be connected to, almost any heat source. In this case, the engine is connected to a heat source of a solar collector. On the other hand, the collector system that is in charge of providing heat to the engine is inserted on top of the Stirling model. Details regarding the engine model can be found in [30] and therefore the equations are not presented in this paper. The collector model is, however, presented below. The heat supplied to the Stirling is determined by calculating the total efficiency of the solar collector, including the concentrator dish and the receiver.

$$
Q_{\text {high }}=S \cdot A_{\text {conc }} \cdot N_{\text {unit }} \cdot \eta_{\text {conc }} \cdot \eta_{\text {rec }}
$$

where $S$ is the direct solar radiation per area, $A_{\text {conc }}$ is the area of the concentrator, $N_{\text {unit }}$ is the number of units, $\eta_{\text {conc }}$ is the concentrator efficiency, and $\eta_{\text {rec }}$ is the receiver efficiency. The optical efficiency of the dish concentrator is assumed to be constant (including reflectivity and interception factor) while the receiver efficiency is modeled taking into account the heat losses [31] as

$$
\eta_{r e c}=\alpha \tau-\frac{U_{C C}\left(T_{r e c}-T_{a m b}\right)+\varepsilon \sigma\left(T_{r e c}^{4}-T_{s k y}^{4}\right)}{\eta_{c o n c} C_{R} S}
$$

where $\varepsilon$ is the emissivity of the receiver, $\sigma$ is the Boltzmann constant $\left(5.67 \times 10^{-8} \mathrm{~W} / \mathrm{m}^{2} \mathrm{~K}^{4}\right)$, and $C_{R}$ is the concentration ratio. $T_{r e c}, T_{s k y}$ and $T_{a m b}$ are the receiver, sky and ambient temperatures, respectively. $\alpha$ and $\tau$ are absorptance and transmittance, respectively, and are assumed to be constant. As a result, the model does not take into account the performance variation due to solar incidence angle variations $\left(K_{\gamma \tau \alpha}=1\right)$. However, the error (if present) will be insignificant/negligible because the full tracking system is usually accurate, and diminishes the error (if any). Further, since there is no cover, the value for transmissivity as well as absorptivity, would be close to one (maximum possible). The $U_{C C}$ is the combined convection-conduction heat loss coefficient accounting for convection to the ambient environment and conduction through the structure. It is calculated as

$$
U_{C C}=\frac{h_{\text {wind }}}{1-U_{\text {sup_ratio }}}
$$

where $U_{\text {sup_ratio }}$ is the loss through the supports of the structure, and $h_{\text {wind }}$ is the heat transfer convection coefficient for wind, and is defined as [31]

$$
h_{\text {wind }}=\frac{k_{\text {air }}}{D_{\text {rec }}} 0.3 \operatorname{Re}_{\text {wind }}^{0.6}
$$




$$
\operatorname{Re}_{\text {wind }}=\frac{\rho_{\text {air }} V_{\text {wind }} D_{\text {rec }}}{\mu_{\text {air }}}
$$

where $k_{\text {air }}, \rho_{\text {air }}$ and $\mu_{\text {air }}$ are the properties of air as conductivity, density, and viscosity, respectively, while $V_{w}$ and $D_{\text {rec }}$ are wind velocity and receiver diameter, respectively.

Finally, the generated power can then be calculated by

$$
\begin{aligned}
& P_{\text {total }}=P_{\text {mech }} \eta_{\text {gen }}-Z_{\text {track }} N_{\text {unit }} \\
& \eta_{\text {total }}=\frac{P_{\text {mech }}}{\eta_{\text {conc }} \eta_{\text {rec }} \eta_{\text {gen }} Q_{\text {high }}}
\end{aligned}
$$

where $Z_{\text {track }}$ is the tracking system power. $P_{\text {mech }}$ and $Q_{\text {high }}$ are the power generated by the Stirling engine and heat supplied to the engine, respectively. The mechanical power of the Stirling engine as well as other parameters are assumed according to [29]. Table 3 provides the specifications for the Dish-Stirling.

Table 3. Specifications for Dish-Stirling.

\begin{tabular}{l|l}
\hline Dish-Stirling & \\
\hline Number of units $\left(N_{\text {unit }}\right)$ & 175 \\
Absorber & $1.2 \mathrm{~m}$ \\
\hline Diameter $\left(D_{\text {rec }}\right)$ & 0.93 \\
Absorptivity $(\alpha)$ & 0.93 \\
Transmittance $(\tau)$ & 0.90 \\
Emissivity $(\varepsilon)$ & $770^{\circ} \mathrm{C}(1043 \mathrm{~K})$ \\
Wall temperature $\left(T_{\text {rec }}\right)$ & \\
Stirling & Helium \\
Gas & $700^{\circ} \mathrm{C}(973 \mathrm{~K})$ \\
Hot gas temperature & $50^{\circ} \mathrm{C}(323 \mathrm{~K})$ \\
Cool Wall to Gas $\Delta \mathrm{T}$ & 1.4 \\
Compression ratio & 0.95 \\
Regenerator effectiveness & 0.9 \\
Mechanical loss factor & \\
Concentrator & 0.851 \\
\hline Efficiency $\left(\eta_{\text {conc }}\right)$ & $10.57 \mathrm{~m}$ \\
Diameter $\left(D_{\text {conc }}\right)$ & 2793 \\
Concentration ratio $\left(C_{R}\right)$ & $60 \mathrm{~W}$ \\
Tracking power $\left(Z_{\text {track }}\right)$ & $95 \%$ \\
Generator efficiency $\left(\eta_{\text {gen }}\right)$ & $20 \%$ of the heat to ambient \\
Manifold losses $\left(U_{\text {sup_ratio }}\right)$ & \\
Other Information & 800 \\
\hline Irradiation, $S\left[\mathrm{~W} / \mathrm{m}^{2}\right]$ & $28^{\circ} \mathrm{C}(301 \mathrm{~K})$ \\
Ambient temperature $\left(T_{\text {amb }}\right)$ & $22^{\circ} \mathrm{C}(295 \mathrm{~K})$ \\
Sky temperature $\left(T_{\text {sky }}\right)$ & $2 \mathrm{~m} / \mathrm{s}$ \\
Wind velocity $\left(V_{\text {wind }}\right)$ & \\
\hline
\end{tabular}

\subsection{Modeling of PTSC-SG (Steam Generator)}

A model for the steam generator PTSC is developed by combining the models presented in [32], [33] and [34]. In short, the model calculates the outlet steam state conditions from the water flow inlet and the external atmospheric conditions. The model includes calculations of heat losses and pressure 
drops along the pipe. The input parameters are the direct solar radiation, solar ray's angle of incidence, wind velocity, ambient temperature, sky temperature, the number of rows and the length. Other dimensions and optical characteristics of the unit, such as pipe aperture $(w)$, receiver diameter $(D)$, reflectivity $(\rho)$ and absorptance $(\alpha)$, are also included in the model. The model equally distributes the total incoming mass flow between the numbers of rows. Then, it divides the receiver into three sections depending on the water state, i.e., whether the water is liquid (section 1), saturating (section 2) and superheated steam (section 3 ) to account for different water states and their different properties.

First, the model calculates the outlet pressure as

$$
p_{\text {out }}=p_{\text {in }}-\Delta p=p_{\text {in }}-\Delta p_{1}-\Delta p_{2}-\Delta p_{3}
$$

where $\Delta p_{1}, \Delta p_{2}$ and $\Delta p_{3}$ are the pressure drops at different sections defined above. Thus, the total pressure drop along each tube would be the sum of the pressure drops in each section. For the singlephase flow (section 1 and 3), the pressure drop is calculated by the Darcy-Weisbach correlation [35]. The Colebrook correlation, defines the friction coefficient $(f)$ as

$$
\begin{array}{lc}
\Delta p_{s}=f_{s} \rho_{m, s} \frac{V_{m, s}^{2}}{2 D_{r i}} L_{s} & s=1 \text { and } 3 \\
\frac{1}{\sqrt{f_{s}}}=-2 \log _{10}\left(\frac{r_{r}}{3.7}+\frac{2.51}{\operatorname{Re} \sqrt{f_{s}}}\right) & s=1 \text { and } 3
\end{array}
$$

where $\rho_{m, s}$ and $V_{m, s}$ are the average density and velocity of the flow in the section $s$, respectively, and $D_{r i}$ is the inner diameter of the receiver. The relative roughness $r_{r}=\delta / D_{r i}$, where $\delta$ is the absolute roughness of the pipe material. For example, the absolute roughness for stainless steel is $1.5 \times 10^{-5} \mathrm{~m}$ ( see [36]). It is important to mention that the pressure drop in the first section will define the saturation pressure, and therefore, the saturation temperature will also be known. However, the length of the first section must be determined first by determining the heat demand.

In the second section, as there is a boiling flow where the two phases coexist, the pressure drop is calculated differently by using the Friedel correlation [37]. This correlation assumes that each phase is flowing separately at different velocities and occupying a given fraction of the pipe cross section (separated model).

$$
\Delta p_{2}=\Delta p_{2 p h}=\Delta p_{\text {static }}+\Delta p_{\text {momentum }}+\Delta p_{\text {friction }}
$$

It can be seen that the total pressure drop is divided in three parts: static, momentum and friction pressure drops. The static pressure drop is assumed to be zero because the receiver is placed horizontally. The momentum pressure drop depends on the inlet and outlet states, which assumes the complete evaporation from pure liquid to pure vapor discussed in [37],

$$
\Delta p_{\text {momentum }}=\dot{G}^{2}\left(1-\frac{1}{\rho_{L}}\right)
$$

With the mass velocity $\dot{G}=\dot{m} / A_{\text {cross }}$, where $A_{\text {cross }}$ is the cross-sectional area of the pipe, and $\dot{m}$ is the mass flow. $\rho_{L}$ is the density of the liquid phase.

The friction factor is calculated based on the pressure drop as if all fluid is in a liquid state. A twophase multiplier is then applied to account for phase changes. The total friction factor depends also on the distance travelled by the fluid, and as the vapor qualities vary along the pipe, the pipe has to be discretized into $N$ segments. The pressure drop in each segment is then calculated individually, and finally, the individual pressure drops are summed to obtain the total pressure drop. 
and

$$
\Delta p_{\text {friction }}=\sum_{z=1}^{N} \Delta p_{L, z} \cdot \phi_{f r, z}^{2}
$$

where the two-phase multiplier is defined as

$$
\phi_{f r, z}^{2}=E_{z}+\frac{3.24 F_{z} H}{F r_{H, z}^{0.045} \cdot W_{H, z}^{0.035}}
$$

409

$$
E_{z}=\left(1-x_{z}\right)^{2}+x_{z}^{2} \frac{\rho_{L} f_{G}}{\rho_{G} f_{L}}
$$

$$
\begin{aligned}
& F r_{H, z}=\frac{\dot{G}^{2}}{g D_{r i} \rho_{H}^{2}} \\
& H=\left(\frac{\rho_{L}}{\rho_{G}}\right)^{0.91}\left(\frac{\mu_{G}}{\mu_{L}}\right)^{0.19}\left(1-\frac{\mu_{G}}{\mu_{L}}\right)^{0.7}
\end{aligned}
$$$$
\text { and } \quad \rho_{H}=\left(\frac{x_{z}}{\rho_{G}}+\frac{1-x_{z}}{\rho_{L}}\right)^{-1}
$$

where $x_{z}$ is the vapor quality, and $\rho_{G}, \rho_{L}, \mu_{G}, \mu_{L}, f_{G}$ and $f_{L}$ are the densities, viscosities and friction coefficients for the gas and liquid state, respectively. $\psi$ is the surface tension, and $g$ is the gravitational constant. All values are mean values in the segment $z$.

Regarding the heat transfer, the flux balance represented is characterized through the equation below:

$$
Q_{\text {absf }, s}=\eta_{\text {opt }} \cdot S \cdot A_{\text {cons }, s}-U_{L} \cdot A_{\text {rec }, s}\left(T_{\text {rom }, s}-T_{\text {amb }}\right) \quad \mathrm{s}=1,2 \text { and } 3
$$

where $Q_{a b s f, s}$ is the heat absorbed by the fluid in section $s, \eta_{o p t}$ is the optical efficiency, $S$ is the irradiation, $T_{a m b}$ is the ambient temperature, $T_{\text {rom,s }}$ is the mean temperature at the outer surface of the receiver in section $s$, and $U_{L}$ is the mean heat transfer coefficient for the entire PTSC. The area of the concentrator in section $s$ is defined as $A_{\text {cons,s }}=$ aperture $\cdot L_{s}$, and similarly, the receiver area in the corresponding section is $A_{r e c, s}=\pi D_{r o} L_{s}$.

First, the optical efficiency is calculated as follows:

$$
\eta_{\text {opt }}=\varphi \gamma \tau \alpha K_{\gamma \tau \alpha}(\beta)
$$

where $\varphi$ is the specular reflectance, and $\gamma$ is intercept factor. The incidence angle modifier $K_{\gamma \tau \alpha}(\beta)$ is usually correlated from experimental results. Owing to a lack of experimental data for this case, the correlation for a similar unit is used here, as in [28]:

$$
K_{\gamma \tau \alpha}(\beta)=1-6.47 \times 10^{-5} \beta^{2}+1.64 \times 10^{-6} \beta^{3}-2.51 \times 10^{-8} \beta^{4}
$$

where $\beta$ is the angle of incidence. Then, the mean heat transfer coefficient for the entire PTSC is determined using the total heat loss to the surrounding environment $\left(Q_{\text {loss }}\right)$, assuming a constant mean temperature of the outer surface of the receiver $\left(T_{\text {rom }}\right)$ and a relative coefficient of the conductive losses through the structure compared with the ambient losses ( $\left.x_{\text {manifold_losss }}\right)$.

$$
U_{L}=\frac{Q_{\text {loss }}}{A_{\text {rec }}\left(T_{\text {rom }}-T_{\text {amb }}\right)} \frac{1}{\left(1-x_{\text {manifold_loss }}\right)}
$$


The manifold loss is assumed to be $20 \%$ of the total loss $\left(x_{\text {manifold_losss }}=0.2\right)$. With the total receiver area $A_{\text {rec }}=\pi D_{r o} L, T_{\text {rom }}$ is calculated as:

$$
T_{\text {rom }}=T_{\text {rom_ } 1} \frac{L_{1}}{L}+T_{\text {rom_2 } 2} \frac{L_{2}}{L}+T_{\text {rom_3 } 3} \frac{L_{3}}{L}
$$

where $T_{\text {rom_l }}, T_{\text {rom } \_} 2, T_{\text {rom_ } 3}, L_{1}, L_{2}$ and $L_{3}$ are calculated from the discretization process described above. The total heat loss along the receiver to the surrounding environment is a combination of conduction, convection, and radiation. First, heat is transferred at the air gap between the receiver and the glass cover by radiation and conduction through the quiescent air in the gap. Then, the heat is transferred through the glass cover thickness by conduction, and finally, heat is transferred to surrounding environment radiation and convection. At steady state, there is a heat flux balance in which the temperatures of the boundary layer remain constant and can be determined by solving the following system:

$$
\begin{aligned}
Q_{\text {loss }}= & \frac{2 \pi L k_{\text {eff }}}{\ln \left(\frac{D_{c i}}{D_{r o}}\right)}\left(T_{r o m}-T_{c i}\right)+\frac{\pi D_{r o} L \sigma\left(T_{r o m}^{4}-T_{c i}^{4}\right)}{\frac{1}{\varepsilon_{r}}+\frac{1-\varepsilon_{c}}{\varepsilon_{r}}\left(\frac{D_{r o}}{D_{c i}}\right)} \\
Q_{\text {loss }}= & \frac{2 \pi L k_{c}}{\ln \left(\frac{D_{c o}}{D_{c i}}\right)}\left(T_{c i}-T_{c o}\right) \\
Q_{\text {loss }}= & \pi D_{c o} L h_{w}\left(T_{c o}-T_{a m b}\right)+\varepsilon_{c} \pi D_{c o} L \sigma\left(T_{c o}^{4}-T_{s k y}^{4}\right)
\end{aligned}
$$

where $k_{e f f}$ is the low-pressure air conductivity, and $D_{r o}, D_{c i}$ and $D_{c o}$ are the diameters of the external surface of the receiver, the inner glass cover and external glass cover, respectively. $\varepsilon_{r}$ and $\varepsilon_{c}$ are the emissivity of the receiver and the glass cover, respectively. $k_{c}$ is the conductivity of the glass cover and $h_{w}$ is the convection coefficient of the wind, which can be calculated in the same way as in the case for the Dish-Stirling model. The Stefan-Boltzmann constant is $5.678 \times 10^{-8} \mathrm{~W} / \mathrm{m}^{2} \mathrm{~K}^{4}$.

The effective conductivity of the low-pressure air trapped in the receiver is calculated by [27]

$$
k_{\text {eff }}=\frac{k_{\text {air }}}{\left(\frac{D_{r o}}{2}\right) \ln \left(\frac{D_{r o}+D_{c i}}{2 D_{r o}}\right)+B \lambda\left(\frac{2 D_{r o}}{D_{r o}+D_{c i}}+1\right)}
$$

$$
\begin{aligned}
& B=\frac{2-C}{C} \cdot \frac{9 Y-5}{2(Y+1)} \quad \lambda=2.331 \times 10^{-10} \frac{T_{m}}{p_{m} \Omega^{2}} \\
& Y=1.37975268+0.00017703 T_{m}-4.2745 \times 10^{-7} T_{m}^{2}+2.0315 \times 10^{-10} T_{m}^{3}
\end{aligned}
$$

where $C$ is the accommodation coefficient which has commonly been assumed to be the value of unity $(C=1)$, and $\lambda$ is the mean free path of the molecules. $\Omega$ is the molecular diameter of air, which is $2.32 \times 10^{-8} \mathrm{~m}$, and $T_{m}$ and $p_{m}$ are the mean temperature and pressure in the annulus (gap), respectively.

The mean temperature at the external surface of the receiver in each section is calculated in order to obtain the $T_{\text {rom }}$. To do that, an energy balance for the pipe wall is performed, resulting in

$$
T_{r o m, s}=T_{f m, s}+\frac{Q_{a b s f_{-} s}}{\pi D_{r o} L_{s} U_{s}} \quad s=1,2 \text { and } 3
$$


where $T_{f m_{-} s}$ is the average temperature of the fluid in section $s$ (sections 1,2 and 3 as defined above), and $U_{s}$ is the overall heat transfer coefficient in section $s$. $U_{s}$ considers the conduction through the pipe wall and convection on the heat transfer fluid side, and is written as

$$
U_{s}=\left[\frac{D_{r o}}{h_{s} D_{r i}}+\frac{D_{r o} \log \left(D_{r o} / D_{r i}\right)}{2 k_{r}}\right]^{-1} \quad s=1,2 \text { and } 3
$$

where $k_{r}$ is the conductivity of the pipe material, and $h_{s}$ is the heat transfer convection coefficient for the fluid side. $h_{s}$ is calculated using different correlations for single-phase and two-phase flows. For the single-phase flow, the Gnielinski correlation is applied, which can be used for a wide range [35], as follows:

$$
h_{s}=\frac{D_{r i}}{k_{s}} \frac{\left(f_{s} / 8\right)\left(\operatorname{Re}_{s}-1000\right) \operatorname{Pr}_{s}}{1+12.7\left(f_{s} / 8\right)^{0.5}\left(\operatorname{Pr}_{s}^{2 / 3}-1\right)}
$$

For two-phase flow (when $s=2$ ), however, the correlation developed by Gungor and Winterton is used [32]. It basically combines the effect of the forced convection and the nucleate boiling weighted with coefficients. Again, similar to the process of calculating the pressure drop in two-phase flow, this section must be discretized into smaller segments because the heat transfer depends on the vapor quality, which varies along the pipe. Thus, the value for $h_{2}$ (two-phase, in the previous equations) is the average value of the $N$ segments defined as

$$
h_{2}=\sum_{Z=1}^{N} h_{2, z}
$$

It was determined that 20 segments were enough for this study. The next step is to calculate the Froude $(F r)$ number [36] in order to distinguish between the flow patterns.

$$
F r=\frac{\dot{G}^{2}}{g D_{r i} \rho_{L}^{2}}
$$

If the $F r$ number is lower than 0.04, then stratified flow occurs, and the Shah correlation [37] is then used, as follows:

$$
\begin{aligned}
& \frac{h_{2, z}}{h_{L}}=3.9 F^{0.24}\left(\frac{x_{z}}{1-x_{z}}\right)^{0.64}\left(\frac{\rho_{L}}{\rho_{G}}\right)^{0.4} \\
& h_{L}=\left(\frac{k_{L}}{D_{r i}}\right) 0.023\left(\frac{\dot{G}\left(1-x_{z}\right) D_{r i}}{\mu_{L}}\right)^{0.8} \operatorname{Pr}^{0.4}
\end{aligned}
$$

where $h_{L}$ is the heat transfer coefficient assuming the liquid fraction that fills the tube and thus the Dittus-Boelter correlation [35] is used. On the other hand, if the $F r$ number is higher than 0.04, then annular flow occurs, and the Chan correlation [37] can be applied, as follows:

$$
\begin{array}{ll}
h_{2, z}=S_{z} h_{B}+F_{z} h_{L, z} & \\
h_{B}=3800\left(\frac{q}{20000}\right)^{n} F_{p} & n=0.9-0.3 p_{r}^{0.15}
\end{array}
$$




$$
F_{P}=2.55 p_{n}^{0.27}\left(9+\frac{1}{1-p_{n}^{2}}\right) p_{n}^{2} \quad p_{n}=\frac{p}{p_{c}}
$$

where $q$ is the heat flux $\left[\mathrm{W} / \mathrm{m}^{2}\right], p$ is the working pressure and $p_{c}$ is the critical pressure $(220.6 \mathrm{bar}$ [38]). The working pressure is the ratio of the saturated pressure to the critical pressure. It is important to note that, even if there is a pressure drop at the two-phase section (see the calculation above), the pressure for heat transfer calculations is assumed to be constant and equal to the pressure of saturation calculated from the pressure drop in the first section.

Oher coefficients are defined as

$$
\begin{aligned}
& S_{z}=\frac{1}{1+1.15 \times 10^{-6} F_{z}^{2}\left[\frac{\dot{G}\left(1-x_{z}\right) D_{r i}}{\mu_{L}}\right]^{1.17}} \\
& F_{z}=1+2.4 \times 10^{4} B o^{1.16 .}+1.37 X_{t t, z}^{-0.86} \\
& X_{t t, z}=\left(\frac{\rho_{G}}{\rho_{L}}\right)^{0.5}\left(\frac{\mu_{G}}{\mu_{L}}\right)^{0.1}\left(\frac{1-x_{z}}{x_{z}}\right)^{0.9}
\end{aligned}
$$

where $B o$ is the boiling number, which is the ratio of mass flux perpendicular to the wall as defined in [32].

Finally, the inlet and outlet temperature of the PTSC are related by the following equation:

$$
Q_{a b s f}=\eta_{o p t} \cdot S \cdot A_{\text {cons }}-U_{L} \cdot A_{\text {rec }}\left(T_{\text {rom }}-T_{a m b}\right)
$$

with $Q_{a b s f}=\dot{m}\left[H_{2}\left(T_{2}, p_{2}\right)-H_{1}\left(T_{1}, p_{1}\right)\right]$, where $H_{1}\left(T_{1}, p_{1}\right)$ and $H_{2}\left(T_{2}, p_{2}\right)$ are the inlet and outlet specific enthalpies, respectively, which are dependent on the temperatures and pressures. $A_{\text {cons }}$ and $A_{\text {rec }}$ are the total areas of the concentrator and receiver, respectively, $\left(A_{\text {cons }}=\right.$ aperture $\cdot L$ and $\left.A_{r e c}=\pi D_{r o} L\right)$. Table 4 provides all other parameters for the PTSC-SG.

The surface tension $\psi$ is modeled as a function of saturated temperature as [39]

$$
\psi=0.11993071-0.00013089\left(T_{\text {sat }}+273.15\right)-9.0999 \times 10^{-8}\left(T_{\text {sat }}+273.15\right)^{2}
$$

Table 4. Main specifications for PTSC-SG.

\begin{tabular}{l|l}
\hline PTSC & \\
\hline Length & $250 \mathrm{~m}$ \\
Number of rows & 20 \\
$\frac{\text { Receiver }}{\text { Diameters }\left(D_{r i}, D_{r o}\right)}$ & $33,38 \mathrm{~mm}$ \\
Material & Stainless steel \\
Conductivity $\left(k_{r}\right)$ & $60 \mathrm{~W} / \mathrm{mK}$ \\
Coating & Black Niquel \\
Emissivity $\left(\varepsilon_{r}\right)$ & 0.06 \\
Absorptivity $(\alpha)$ & 0.94 \\
Cover & \\
Diameters $\left(D_{c i}, D_{c o}\right)$ & $84,90 \mathrm{~mm}$ \\
Material & Glass \\
Conductivity $\left(k_{c}\right)$ & $0.035 \mathrm{~W} / \mathrm{mK}$ \\
Emissivity $\left(\varepsilon_{c}\right)$ & 0.84
\end{tabular}




\begin{tabular}{l|l} 
Transmissivity $(\tau)$ & 0.94 \\
Air pressure in the gap $\left(p_{m}\right)$ & $0.5 \mathrm{mbar}$ \\
Concentrator & \\
\hline Reflectivity $(\varphi)$ & 0.93 \\
Intercept factor $(\gamma)$ & 0.93 \\
Aperture & $2.5 \mathrm{~m}$ \\
Incidence angle modifier $(\beta)$ & 1 \\
Manifold losses & $20 \%$ of the heat to ambient \\
Other Information & \\
\hline Ambient temperature $\left(T_{a m b}\right)$ & $28^{\circ} \mathrm{C}$ \\
Sky temperature $\left(T_{\text {sky }}\right)$ & $20^{\circ} \mathrm{C}$ \\
Wind velocity $\left(V_{\text {wind }}\right)$ & $5 \mathrm{~m} / \mathrm{s}$ \\
Saturation temperature $\left(T_{\text {sat }}\right)$ & $80^{\circ} \mathrm{C}(253 \mathrm{~K})$ \\
\hline
\end{tabular}

\subsection{Modeling of DCMD}

For this component, a hollow fiber configuration is chosen, see Fig. 2. The warm seawater flows in the fibers (the feed side), while cold water flows through the permeate side and is located at the other side of the fibers. It is assumed that the both sides have a constant flow. Owing to the counterflow configuration, the temperature difference along the fiber is almost constant and therefore it is the associated with vapor pressure difference. The pressure gradient (and temperature gradients) across the membrane is the force that drives the entire process.

(a)

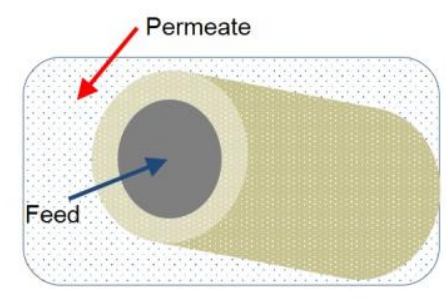

(b)
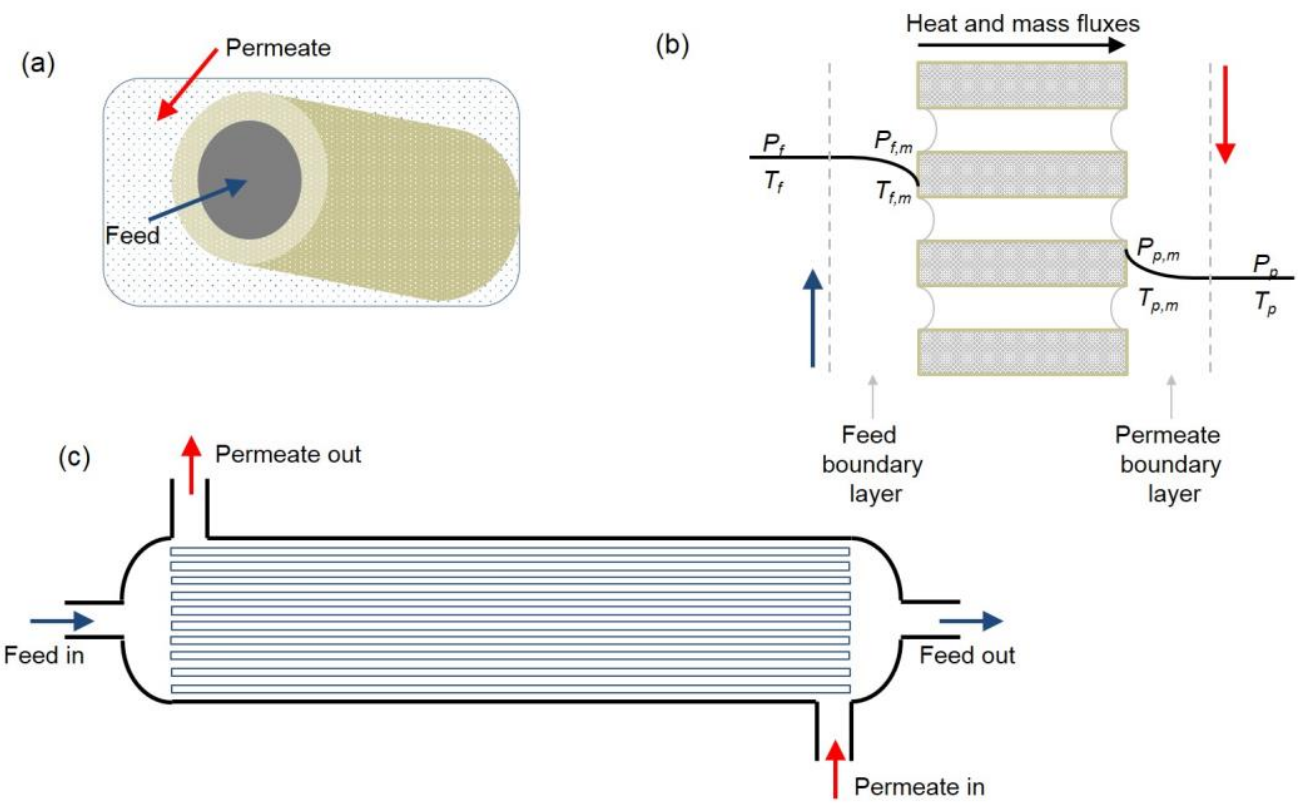

Figure 2. Scheme of a) cross section of the membrane b) the mass and heat transfer through the membrane and c) a complete hollow fibers module.

The modeling along the fiber is performed by dividing the fiber into smaller segments or volumes of control, and applying the balance equations for both mass flow and energy. Mean properties for the segment and the state of each segment (temperature, density, pressure, etc.) are used when calculating the balance equations. Note that if the system is not discretized, then the non-linear behavior of the system leads to large errors in the results. The model is completely based on the modeling approach studied in [40] and therefore the detailed modeling is omitted here.

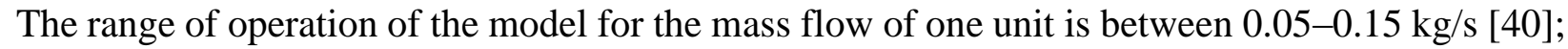
however, higher values can also be used by increasing the number of units. Thus, the model calculates 
the needed for number of units when the mass flow is larger than the limit. In this study, the limit for the range of operation for the feed temperature has limits, and it is set to be between $70^{\circ} \mathrm{C}$ to $90^{\circ} \mathrm{C}$ ( $343 \mathrm{~K}$ to $363 \mathrm{~K})$. The permeate flow is assumed to remain at a constant in-flow of $0.1 \mathrm{~kg} / \mathrm{s}$ in each unit and at $25^{\circ} \mathrm{C}$ at the inlet.

Another important issue to consider, when designing the hollow fiber operation, is the membrane liquid entry pressure (LEP), which sets the limit for the applied transmembrane pressure. Transmembrane pressure is defined as difference between the hydrostatic pressure and the vapor pressure, $\left(p_{p, m}-p_{p}\right)$ and $\left(p_{f}-p_{f, m}\right)$ respectively, (c.f. Fig. 2$)$. Values below such limits will prevent liquid from entering the pores of the membrane. The hydrostatic pressure does not affect the permeate flux, but it is important to consider since it prevents the pores from flooding. Table 5 shows the important data for the DCMD used in study. The seawater is assumed to have a temperature of $15^{\circ} \mathrm{C}$, with a salt concentration of $35 \mathrm{~g} / \mathrm{kg}$.

Table 5. Specifications for the DCMD hollow fiber module.

\begin{tabular}{l|l}
\hline \multicolumn{1}{c|}{ Parameter } & \multicolumn{1}{|c}{ Value } \\
\hline Fiber length & $0.4 \mathrm{~m}$ \\
Inner diameter of fiber & $0.3 \mathrm{~mm}$ \\
Membrane thickness & $60 \mu \mathrm{m}$ \\
Porosity & $75 \%$ \\
Membrane conductivity & $0.25 \mathrm{~W} / \mathrm{mK}$ \\
Shell diameter & $0.003 \mathrm{~m}$ \\
Number of fibers & 3000 \\
Packing density & $60 \%$ \\
Model Constants & $15.18 \times 10^{-4}$ \\
\multicolumn{1}{c}{$C_{k}$} & $5.1 \times 10^{3} \mathrm{~m}^{-1}$ \\
$C_{m}$ & $12.97 \times 10^{-11} \mathrm{~m}$ \\
$C_{p}$ &
\end{tabular}

\section{Plant Configurations}

In short, the plant produces electricity and freshwater at all times by converting the solar energy (24 hours). A dish-Stirling delivers part of its load to the dual mode SOC (reversible solid oxide fuel cell) to produce fuel (hydrogen) during the peak hours of radiation (SOEC mode). Then the plant uses the produced fuel to feed the reversible solid oxide fuel cell to produce electricity during low or zero radiation (SOFC mode). Thus, the plant is able to cover the power demand all the time, and at the same time, it produces freshwater through seawater desalination using the excess heat.

For successful plant operation, it is crucial to develop a management schedule/plan that takes into account the forecast solar radiation, energy demand and fuel supply. The flexibility of the plant in producing power and freshwater will be improved greatly if the schedule is correctly planed.

\subsection{Plant in SOEC Mode}

Fig. 3 shows the SOEC mode operation and is explained below in detail.

1. Water from the tank (point 1) is pumped to the PTSC (point 2), where it is heated and thereby generating steam at $350^{\circ} \mathrm{C}$ (point 3).

2.The steam is then divided into two flows. Part of the steam goes to the RSOC (point 4), and its quantity is regulated according to the electricity surplus from the dish-Stirling units (point 212). The rest of the steam (point 9) is sent to a heat exchanger (SWP1) to preheat seawater (from point 41 to point 42) before it is sent to the condenser/separator (point 10).

3. Before the steam goes to the RSOC (point 4), it flows through a cathode preheater (CP) to gain heat (point 5) from the cathode off-fuel of the RSOC (point 6). The operating temperature of 
the cells is assumed to be $750^{\circ} \mathrm{C}(1023 \mathrm{~K})$, and the steam is preheated to approximately $600^{\circ} \mathrm{C}$ (873K).

4. Preheated steam (5) is fed to the cathode side of the RSOC. Owing to steam electrolysis, the cathode outlet (6) contains a mixture of hydrogen and water, and the anode outlet (point 23) contains oxygen. Both outlets are assumed to have the same temperature as the cell operating temperature $\left(750^{\circ} \mathrm{C}, 1023 \mathrm{~K}\right)$.

5. The off-fuel $\left(\mathrm{H}_{2}+\mathrm{H}_{2} \mathrm{O}\right)$, after leaving the cathode pre-heater (point 7), is cooled once again in another heat exchanger (SWP2) to preheat the seawater (from point 42 to 43). The thermodynamic state at the outlet (point 8 ) is designed to be slightly above the saturation temperature of water.

6. Later in the separator/condenser, the water in the off-fuel mixture (point 8) condenses and mixes with corresponding condensed water in the condenser, allowing for the collection of water at the bottom of the condenser (point 94) and $\mathrm{H}_{2}$ from the top (point 92) at ambient temperature. Water is stored at ambient pressure, while the hydrogen is pressurized and stored (point 11) using the compressor C2 (minimum pressure of 1.5 bar).

7. On the other hand, the oxygen coming out of the anode side (point 23) preheats the seawater in a heat exchanger SWP3 (point 46 to 47) before it is released into the atmosphere (25).

8. The seawater is preheated to $80^{\circ} \mathrm{C}$ (at both 43 and 47) using the heat released from the RSOC outlets, and then are mixed together. The resulting flow (point 48) is used to feed the DCMD units. The outlet is then discharged to the surrounding environment (point 49). On the permeate side, freshwater leaves the tank (point 51) and flows into the DCMD. The outlet (point 52) is used to preheat the seawater (from 45 to 46) in the heat exchanger SWP4 before going to the next heat exchanger (SWP3). Finally, the freshwater out of SWP4 is returned to the tank at ambient pressure.

9. Pumps $\mathrm{P} 2, \mathrm{P} 3$ and $\mathrm{P} 4$ drive the distillation system taking into account the liquid entry pressure limits.

10. At the same time, the dish-Stirling system produces power (point 210) for supplying electricity to the RSOC, while the remaining power is sent to the grid. As the power generated in the dish-Stirling is AC, and the RSOC works with DC (point 211), an inverter is used between these components.

The system is designed in a way that the RSOC in the electrolyzer mode is working at the thermoneutral point (or slightly over) by controlling the steam and the power supplied. Under such operating conditions, minimum power is required by the system and an external heat source (at high temperature level) is not necessary, see e.g. [41].

Regarding the storage system, hydrogen is stored at slightly higher pressure to avoid energy consumption when discharging $\mathrm{H}_{2}$ at ambient pressure again. Pressurized ROEC has also been studied and validated experimentally, see e.g. [42]. However, water is not pressurized to avoid additional energy consumption and also avoiding the greater complexity associated with storing pressurized water.

Further, it is important to keep in mind that the flow entering the separator (point 8) has to be at a temperature that is slightly higher than the condensing temperature of water. Then, the separator will release heat until both water and $\mathrm{H}_{2}$ are at ambient temperature and completely separated in two phases. In order to achieve this, the temperature at point 8 should be the condensing temperature, and pump P1 must deliver the necessary pressure. It is also worth noting that the higher the pressures in point 2, the lower the heat that will be recycled in SWP1. 


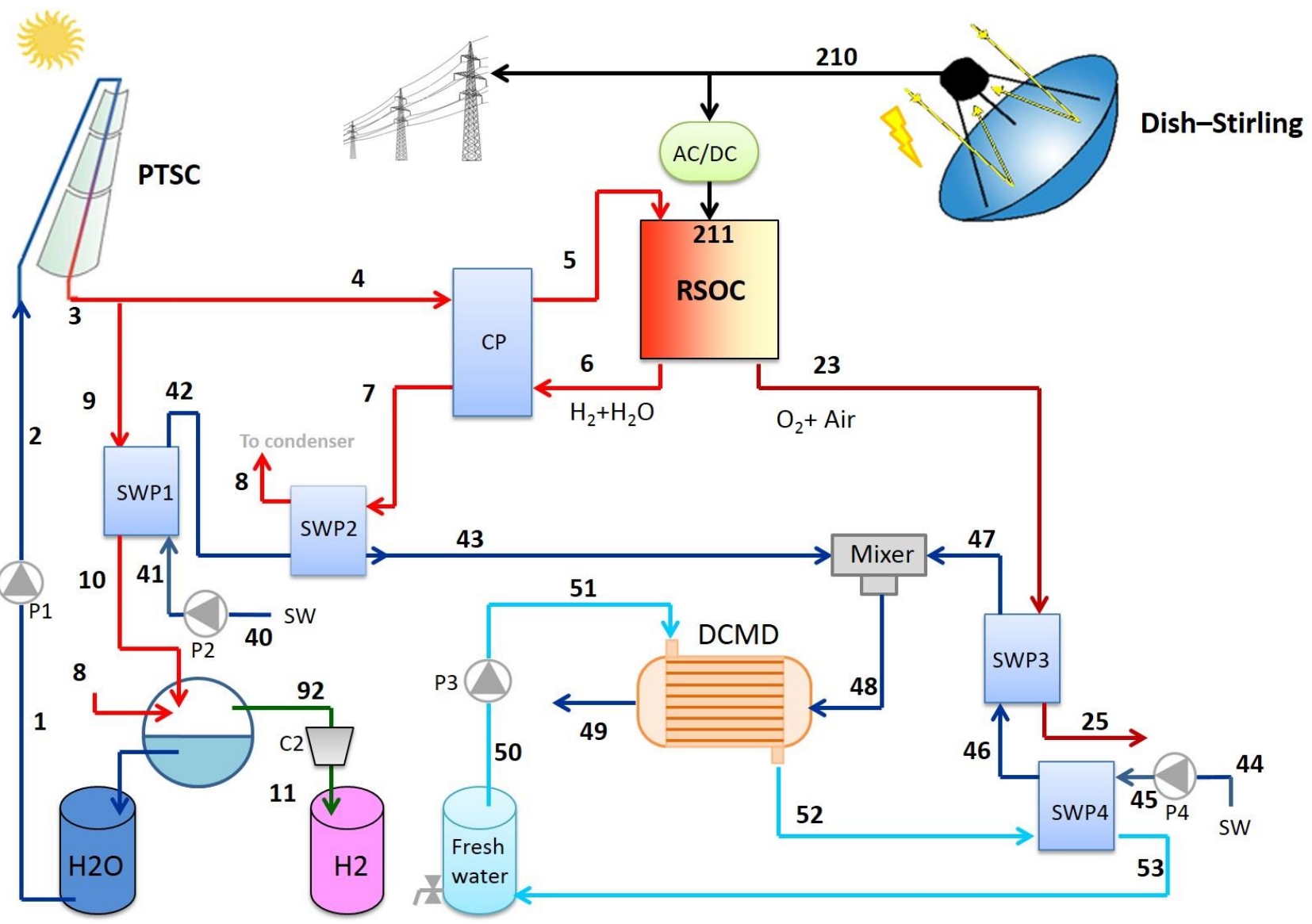

Figure 3. The scheme of SOEC mode operation.

\subsection{Plant in SOEC Mode}

Fig. 4 shows the SOFC mode operation and the plant details is explained below.

1. The heat exchanger, which was a cathode preheater in SOEC mode, is now an anode preheater. In $\mathrm{SOFC}$ mode, the stored $\mathrm{H}_{2}$ (point 16) feeds the anode preheater.

2. A blower (C1) supplies air to the cathode side of the RSOC (point 20). Pressure drops along the air pass-way decide the pressure of the air after it leaves the blower. A heat exchanger (AP) preheats the air before it enters the cathode side of the RSOC (from 21 to 22). Off-air out of the cathode (point 23), which is approximately $150^{\circ} \mathrm{C}$ warmer, preheats the incoming air.

3. The reactions taking place in the SOEC are now reversed when compared to the SOFC mode. As a result, the off-fuel at the anode outlet (point 6) will be composed mostly of water and hydrogen, while the off-air at the cathode outlet (point 23) will be composed of air and poor in oxygen.

4. In this mode, all the steam generated at the PTSC (point 9) is used to feed the heat exchanger (SWP1) and preheat the seawater (from point 41 to 42 ).

5. The dish-Stirling system is still producing power, but less than in the SOEC mode, owing to less radiation. However, the RSOC is now able to produce power (point 211) using the stored fuel. An inverter converts the power produced by RSOC from DC to AC and sends it to the grid (point 212). 


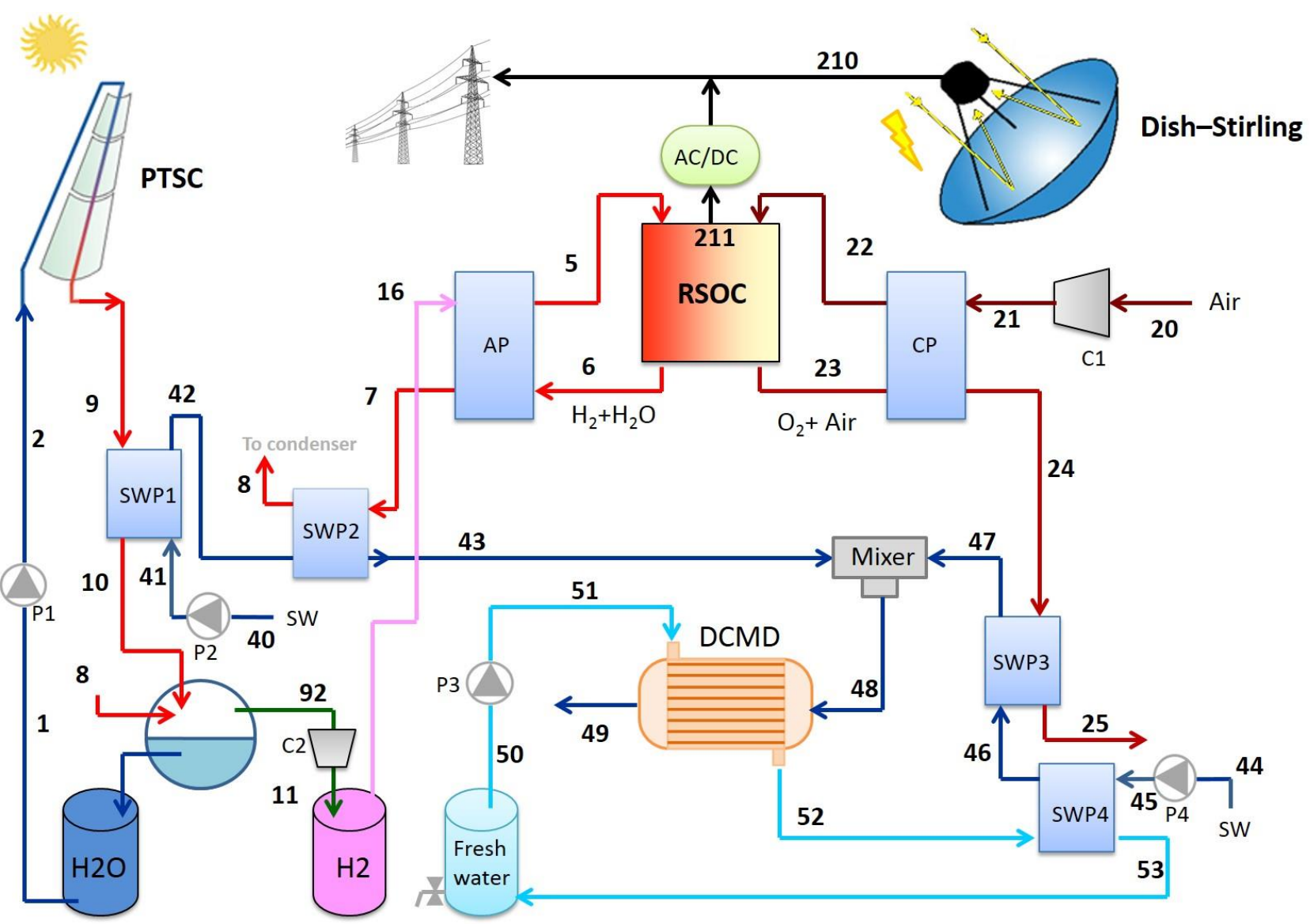

Figure 4. The scheme of SOFC mode operation.

\subsection{Sizing and Dimensioning the Plant}

The dish-Stirling collectors and the storage system are the two main subsystems in the plan and both can be scaled up by adding more collector units or solid oxide cell stacks, respectively. One can optimize the size of these subsystems and achieve a reliable power supply by estimating the power demand during the daytime. First, it is necessary to make sure that the main component of the storage system (the RSOC) can deliver the maximum demanded power. Once a minimum RSOC size is set, one should look at the performance and needs of the RSOC when the system is operating in electrolysis mode, such as the power and mass flow of steam at a fixed temperature. Afterwards, one needs to define the number of rows and length of the PTSC, as well as the number of dish-Stirling units, by taking into account the solar radiation and meet the SOECs power demand. Note that the dish-Stirling units need to cover not only the SOEC demand but also the power demand through the grid.

The next step is to evaluate the system against an estimated solar irradiation profile, in order to check whether the system is self-sufficient, meaning that the net balance of hydrogen is positive (production versus usage). If not, then the size of the RSOFC needs to be increased to produce more hydrogen. This, in turn, means that one needs to increase the number of dish-Stirling units. On the other hand, in order to ensure that steam is not condensing before reaching the condenser (point 10), one needs to set the minimum temperature at point 2 as the saturation temperature (approximately $\left.180^{\circ} \mathrm{C}, 453 \mathrm{~K}\right)$.

The pressure drops should also be taken into account in the system design. Pump 1 (P1 in the figures) is in charge of driving the water and associated pressure drops along its way until the condenser. This pressure should not be too high either because as the higher the pressure is, the higher the temperature of condensation will be, and therefore less heat will be available for seawater preheating at point 7 . In addition, the pressure in the distillation system should also be considered. Pump 3 (P3) has to provide enough pressure to overcome the pressure losses in the DCMD and SWP4 
before the water reaches the fresh water tank. At the same time, the DCMD operation limits the membrane liquid entry pressure and therefore the possibility to recover the heat at the outlet of the permeate side is then conditioned by the pressure drop in the heat exchanger (SWP4).

The ambient conditions are assumed to be $30^{\circ} \mathrm{C}$ for air temperature, $20^{\circ} \mathrm{C}$ for sky temperature and $5 \mathrm{~m} / \mathrm{s}$ for wind speed. The main parameters for the other components are listed in Table 6 . Note that the current study neglects the heat losses to the surroundings and therefore resizing the proposed plant does not affect the results obtained here. In a real plant the heat losses to the surroundings decreases proportionally when plant size is increased and therefore better performance will be achieved.

Table 6. Specifications for auxiliary components.

\begin{tabular}{l|l}
\hline Efficiency of pumps & 0.95 \\
Effectiveness of Heat exchangers & 0.8 \\
Mechanical efficiency of compressors & 0.95 \\
Isentropic efficiency of compressors & 0.7 \\
Efficiency of inverter/rectifier & 0.95 \\
\hline
\end{tabular}

Table 7 presents the parameters for the streams shown in Fig. 3 and Fig. 4. The values for the SOEC case a for a typical summer day at 8:00 o'clock in the morning while the values for the SOFC case are during the night when solar radiation is not available or is too low to provide the power demand. In the columns the first value is for the SOEC case while the second value is for the SOFC case.

Table 7. Parameters of streams in Fig. 3 and Fig. 4. SOEC is a typical summer day at 8 o'clock in the morning.

\begin{tabular}{|c|c|c|c|}
\hline Point in Fig. 3 and 4 & $\begin{array}{c}\text { Mass Flow [kg/s] } \\
\text { SOEC / SOFC }\end{array}$ & $\begin{array}{c}\text { Temperature }\left[{ }^{\circ} \mathrm{C}\right] \\
\text { SOEC / SOFC }\end{array}$ & $\begin{array}{l}\text { Pressure [bar] } \\
\text { SOEC / SOFC }\end{array}$ \\
\hline 1 & $0.39 / 0.11$ & $25.00 / 25.02$ & $1.013 / 1.013$ \\
\hline 2 & $0.39 / 0.11$ & $25.04 / 25.03$ & $7.000 / 5.000$ \\
\hline 3 & $0.39 /-$ & $350.0 /-$ & $6.296 /-$ \\
\hline 4 & $0.08 /-$ & $350.0 /-$ & $6.296 /-$ \\
\hline 5 & $0.08 / 0.01$ & 614.8 / 606.0 & $6.196 / 1.400$ \\
\hline 6 & $0.02 / 0.06$ & $750.0 / 750.0$ & $6.146 / 1.386$ \\
\hline 7 & $0.02 / 0.06$ & 430.0 / 291.4 & $6.136 / 1.376$ \\
\hline 8 & $0.02 / 0.06$ & $180.0 / 180.0$ & $6.126 / 1.366$ \\
\hline 9 & $0.32 / 0.11$ & $350.0 / 180.0$ & $6.296 / 4.893$ \\
\hline 10 & $0.32 / 0.11$ & $180.0 / 180.0$ & $6.286 / 4.883$ \\
\hline 11 & $0.01 / 0.00$ & $30.00 / 30.00$ & $6.026 / 1.266$ \\
\hline 16 & $-/ 0.01$ & $-/ 30.00$ & $-/ 1.500$ \\
\hline 20 & $-/ 2.37$ & $-/ 30.00$ & $-/ 1.013$ \\
\hline 21 & $-/ 2.37$ & $-/ 40.00$ & $-/ 1.097$ \\
\hline 22 & $-/ 2.37$ & $-/ 608.0$ & $-/ 1.087$ \\
\hline 23 & $0.06 / 2.31$ & $750.0 / 750.0$ & $6.146 / 1.033$ \\
\hline 24 & $-/ 2.31$ & $-/ 185.32$ & $-/ 1.023$ \\
\hline 25 & $0.06 / 2.31$ & $90.00 / 90.00$ & $6.136 / 1.013$ \\
\hline 40 & $0.51 / 0.06$ & $15.02 / 15.02$ & $1.013 / 1.013$ \\
\hline 41 & $0.51 / 0.06$ & $15.02 / 15.02$ & $2.000 / 2.000$ \\
\hline 42 & $0.51 / 0.06$ & $64.64 / 15.03$ & $1.900 / 1.900$ \\
\hline 43 & $0.51 / 0.06$ & $80.00 / 80.00$ & $1.800 / 1.800$ \\
\hline 44 & $1.03 / 1.98$ & $15.02 / 15.02$ & 1.013 / 1.013 \\
\hline 45 & $1.03 / 1.98$ & $15.02 / 15.02$ & $2.000 / 2.000$ \\
\hline 46 & $1.03 / 1.98$ & $71.20 / 52.81$ & $1.900 / 1.900$ \\
\hline 47 & $1.03 / 1.98$ & $80.00 / 80.00$ & $1.800 / 1.800$ \\
\hline
\end{tabular}




\begin{tabular}{c|c|c|c}
\hline 48 & $1.54 / 2.04$ & $80.00 / 80.00$ & $1.800 / 1.800$ \\
49 & $1.48 / 1.96$ & $40.32 / 41.34$ & $1.390 / 1.381$ \\
50 & $1.10 / 1.40$ & $25.00 / 25.00$ & $1.013 / 1.013$ \\
51 & $1.10 / 1.40$ & $25.00 / 25.00$ & $1.419 / 1.415$ \\
52 & $1.16 / 1.48$ & $75.00 / 75.54$ & $1.113 / 1.113$ \\
53 & $1.16 / 1.48$ & $25.02 / 25.02$ & $1.013 / 1.013$ \\
92 & $0.01 / 0.00$ & $180.00 / 180.00$ & $6.126 / 1.366$ \\
\hline
\end{tabular}

\section{Results and discussions}

Simulations and main calculations were carried out using dynamic network analysis (DNA), which is an in-house software for energy systems analysis developed at the DTU Thermal Energy Section. DNA solves a system of non-linear equations through the Newton-Raphson modified algorithm, see, for example, [43]. The models were verified against the literature to assure quality of the results, but the verification is not reported here owing to limited space. In the sections that follow, the performance of each component is presented along with discussions of some of the interesting aspects of the components' performances.

\subsection{Models Validation}

For the DCMD model, the model is tested against the results study of [44]. There are many different parameters to compare but one of the most relevant parameter for the plant will be the transmembrane flux or water distilled depending based on the inlet mass flow of the feed side. The temperature of the feed flow is assumed to be $75^{\circ} \mathrm{C}$ while the temperature and mass flow of the permeate flow are assumed to be $25^{\circ} \mathrm{C}$ and $0.1 \mathrm{~kg} / \mathrm{s}$, respectively. The model gives $12 \mathrm{~kg} / \mathrm{m}^{2} \mathrm{~h}$ of freshwater at $0.15 \mathrm{~kg} / \mathrm{s}$ of feed flow which is exactly the same as in [44].

To validate PTSC, first the heat losses from the outer surface of the receiver to the ambient are compared with the results in [45] when there is no sun. The model gives $96.7 \mathrm{~W} / \mathrm{m}$ heat losses to the surrounding when the temperature difference with the surrounding is $200^{\circ} \mathrm{C}$. The corresponding value in [45] can be read about $97 \mathrm{~W} / \mathrm{m}$. Another parameter to be compared is the power absorbed at a certain radiation. The model gives $44.3 \mathrm{~kW}$ at $1000 \mathrm{~W} / \mathrm{m}^{2}$ radiation, while the corresponding value in the study of [10] reads about $42 \mathrm{~W} / \mathrm{m}^{2}$.

Regarding the dish-Stirling, the model developed is compared with the study of [46]. Using the same data such as absorber temperature, concentrating ratio, radiation, etc. the model gives dishStirling efficiency of about 0.33 while the same value can be read from [46] as about 0.32 when absorber temperature is $1400 \mathrm{~K}$.

The SOEC model developed here gives a cell voltage of $1.29 \mathrm{~V}$ for the current density of 2693 $\mathrm{A} / \mathrm{m}^{2}$ and cell temperature of $900^{\circ} \mathrm{C}$, which is very close to the experimental value of about $1.3 \mathrm{~V}$ shown in the study of [10]. Similarly, the SOFC model developed here has already been compared with experimental data in previous publications and very good results were obtained, see

\subsection{Irradiation}

In order to study the possibility of such technique one needs to run the system under knowledge of irradiation in the area under consideration. Here the case study will be limited to Denmark, also an area where solar radiation is relatively low compared to the other countries. According to [47], the irradiation in Nordic European countries is less than about $1500 \mathrm{~W} / \mathrm{m}^{2}$. In this study seven characteristic days are selected according to Fig. 5. As seen in this figure, the highest irradiation is lower than $1000 \mathrm{~W} / \mathrm{m}^{2}$ meaning that a conservative values are chosen here. The peak irradiation is selected to be at 13 and it decreases towards evening and morning as shown in the figure. On characteristic summer day is selected while two characteristic days for spring, fall and winter are 
selected. The reason is to account for some cloudy days during spring, fall and winter. The peak for summer day is assumed to be $930 \mathrm{~W} / \mathrm{m}^{2}$ while the peak for the two winter days are assumed to be about 605 and $558 \mathrm{~W} / \mathrm{m}^{2}$. These data are validated and compared with the date available in [48] and the daily variation is similar to the measured data reported in [49], which is very detailed.

The demand is assumed to be $500 \mathrm{~kW}$ constant all day long, for the entire year and regardless of the season. Although, one could assume that the demand would decrease slightly during nighttime but this is not considered here for the sake of simplicity. It is also assumed that there is $300 \mathrm{~kg} \mathrm{of}_{2}$ in the tank and then the amount of produced hydrogen is added to the stock. Thereby one can calculate the amount of $\mathrm{H}_{2}$ at the end of the day and compare it with the beginning of the day. The produced freshwater is just added to the corresponding tank/reservoir.

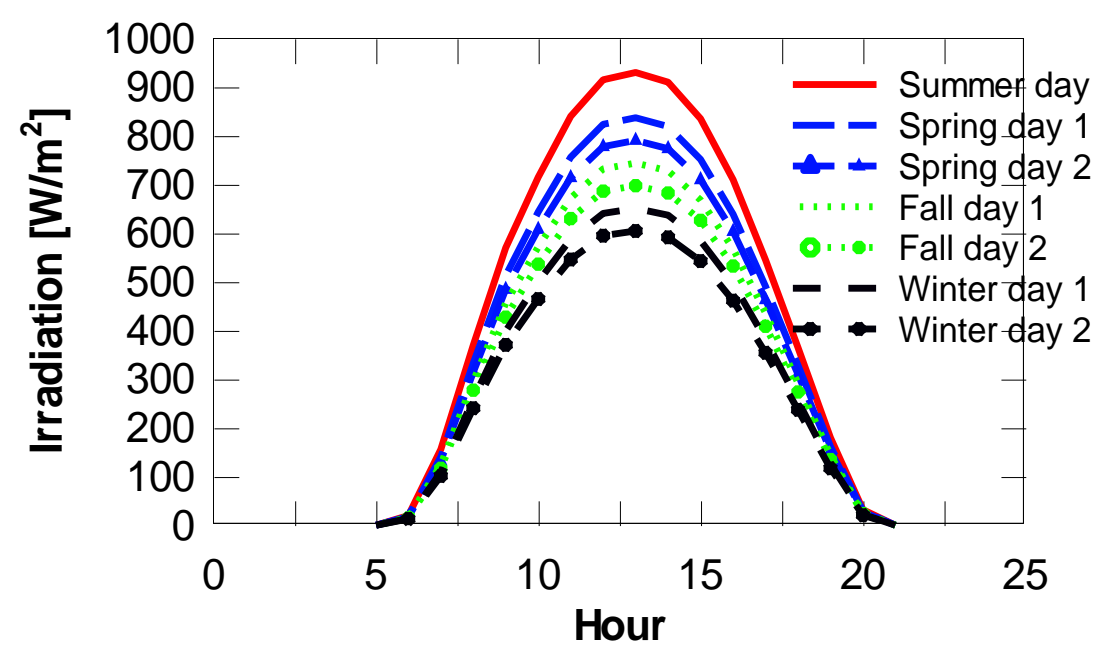

Figure 5. Selected irradiation days in this study, one summer day, two spring, fall and winter days.

The first study concerns how much the dish-Stirlings can produce power as function of solar irradiation and thereby fulfill the demand. Fig. 6 displays that when the irradiation is about $270 \mathrm{~W} / \mathrm{m}^{2}$ then the power delivered to the grid is lower than the demand. It means that at this point the SOFC will act as SOEC mode to use the produced $\mathrm{H}_{2}$ and generate electricity to cover the power demand.

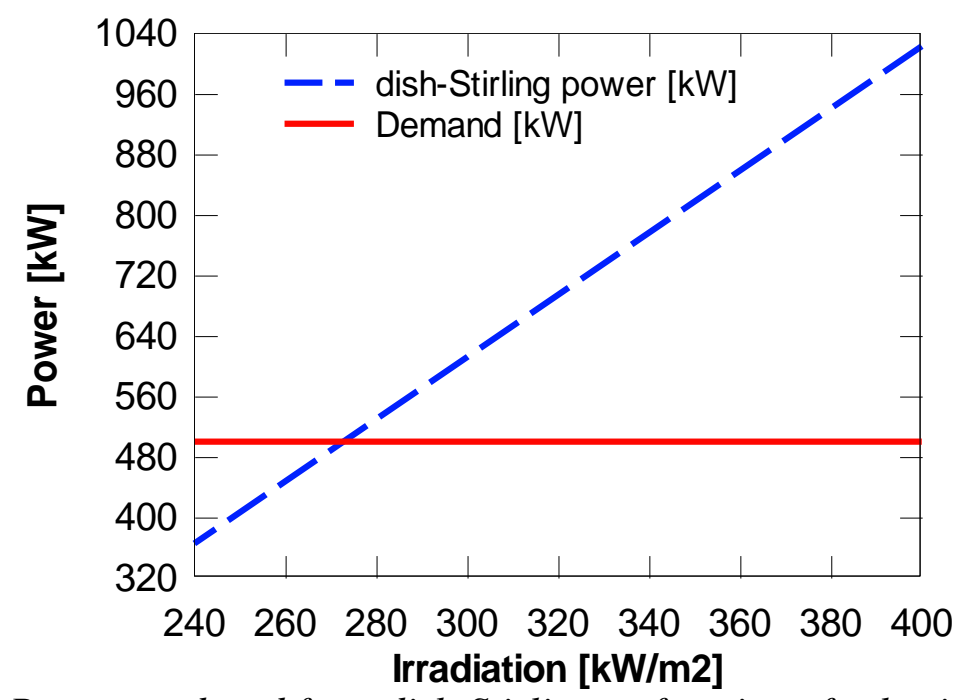

Figure 6. Power produced from dish-Stirling as function of solar irradiation.

\subsection{Summer day}

Figure 7 shows the power produced by the dish-Stirlings during 24 hours. As seen, the produced power starts at 8 o'clock and increases sharply until 13 o'clock when the solar radiation is the highest. 
Afterwards, the produced power declines as the solar radiation starts to decrease from midday (13 o'clock). The produced power stops at 19 o'clock when the solar radiation is too low and therefore the solar dishes cannot produce enough power to fulfill the demand. At this time the SOEC mode will changed into SOFC mode and the plant starts to consume hydrogen to produce power and fulfill the demand. The plant consumes from 19 in the afternoon until 8 in the morning when the SOFC mode switches back into SOEC again. Note also that the radiation starts at 6 in the morning but the plant mode is still SOFC, the reason is that the radiation is too low (below about $200 \mathrm{~kW} / \mathrm{m}^{2}$ ) and with such low radiation the solar dishes cannot produce enough power $(500 \mathrm{~kW})$. Other important pint to be mentioned is that the highest radiation in this particular summer day is $930\left[\mathrm{~kW} / \mathrm{m}^{2}\right]$ which is below the value reported in [47] for Nordic European countries.

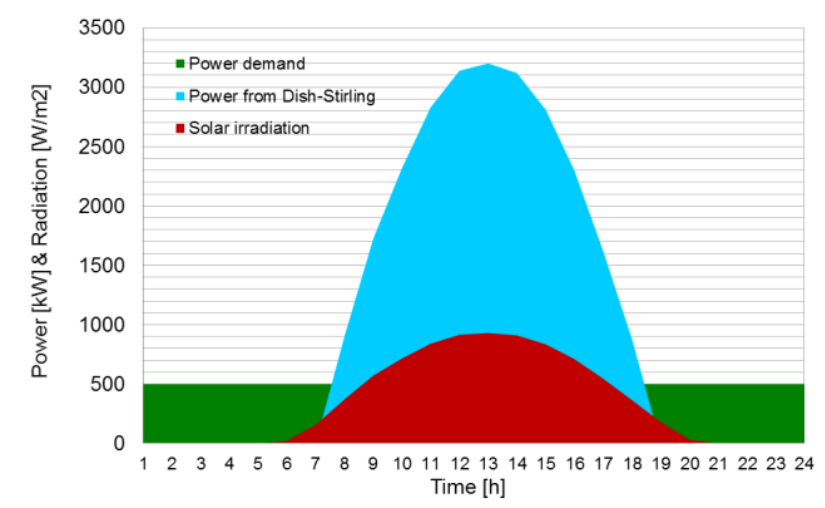

Figure 7. Solar irradiance $\left[\mathrm{kW} / \mathrm{m}^{2}\right]$ and power produced from dish-Stirling $\left[\mathrm{kW} / \mathrm{m}^{2}\right]$ in comparison with the power demand for the assumed summer day.

Figure 8 shows the produced freshwater and the variation of hydrogen in the tank during this particular summer day. As demonstrated, during the nighttime (between 19 in the afternoon to 7 in the morning) the plant is consuming hydrogen indication running on SOFC mode. During the daytime hydrogen amount is increasing meaning that the plant is running on SOEC mode (from 8 in the morning to 18 in the afternoon). The very interesting point is that the amount of hydrogen in the stock is much higher at the end of the day than the day starts (midnight 00 o'clock). The hydrogen in the tank is $300 \mathrm{~kg}$ when the day starts but it is about $650 \mathrm{~kg}$ when the ends, also more than double. This is corresponding to about $7400 \mathrm{sm}^{3}$ (standardized $15^{\circ} \mathrm{C}$ and $1.01325 \mathrm{bar}$ ) of hydrogen.

Freshwater production increases continuously since no water consumption is assumed in this study. The plant produces about $8700 \mathrm{~kg}$ freshwater at the end of the day. The rate of freshwater production increases when solar radiation is high from about 11 in the morning to 15 in the afternoon.

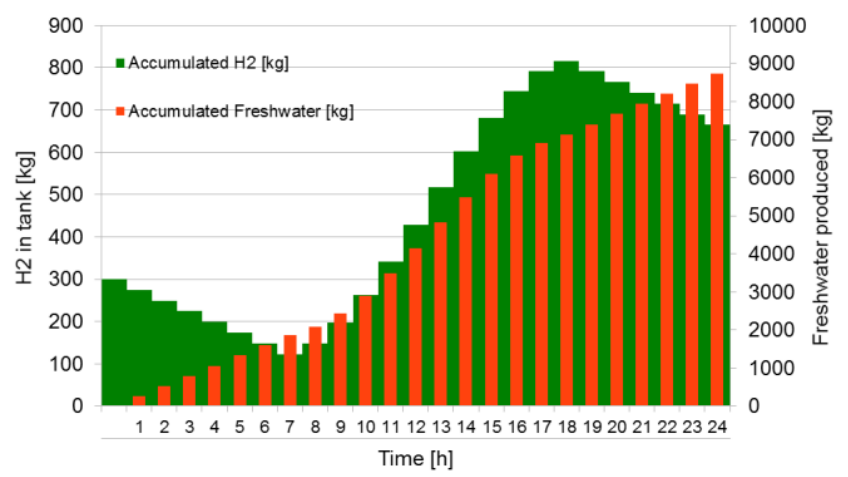

Figure 8. Hydrogen and freshwater variation in the stock for the assumed summer day.

\subsection{Spring days}


Two days are representing this season, one with higher solar radiation and one for lower irradiation, see Fig. 9. The peak solar irradiation for day 1 is about $840\left[\mathrm{~kW} / \mathrm{m}^{2}\right]$ while it value for day 2 is $790\left[\mathrm{~kW} / \mathrm{m}^{2}\right]$, also $5 \%$ lower. Again the power demand is $500 \mathrm{~kW}$ continuously as displayed in the figure. Similar to the summer day, the plant is running on SOEC mode (consuming fuel) from 8 in the morning to 18 in the afternoon and switches to SOFC mode at 19 in the afternoon. This is valid for both particular days.

At the end of the day, the produced hydrogen increases from $300 \mathrm{~kg}$ to about $579 \mathrm{~kg}$ for day 1 which is substantially lower than the case for the summer day, see Fig. 10a. The hydrogen content increases from $300 \mathrm{~kg}$ to about $536 \mathrm{~kg}$ for the chosen second day (day 2 in Fig. 10b). Freshwater production at the end of day 1 is about $8050 \mathrm{~kg}$ while the corresponding value for second day is about $7720 \mathrm{~kg}$. Both these values are significantly lower than the case for summer day.

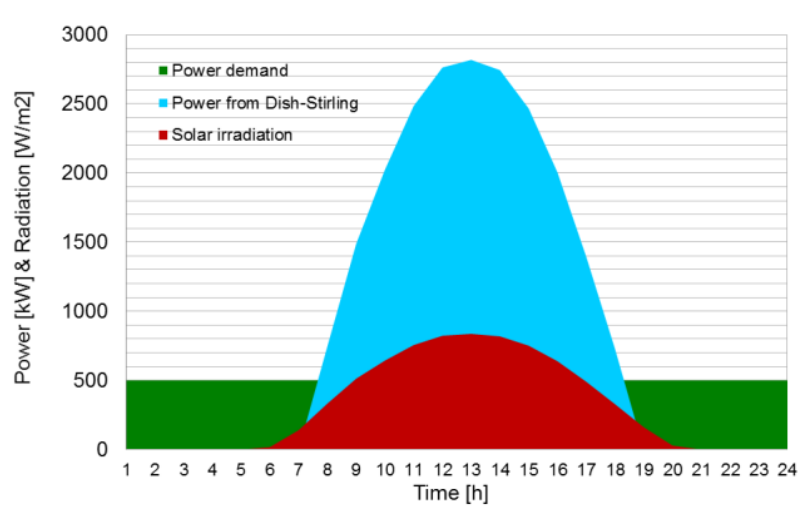

a) Day 1

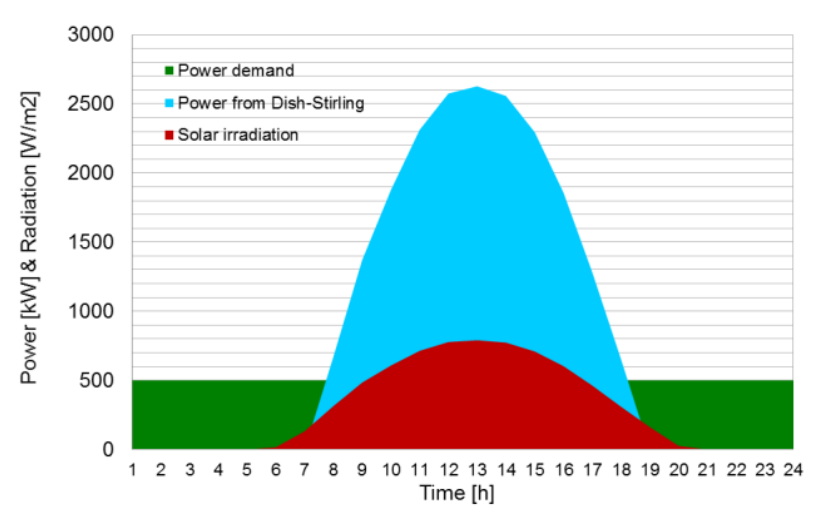

b) Day 2

Figure 9. Solar irradiance $\left[\mathrm{kW} / \mathrm{m}^{2}\right]$ and power produced from dish-Stirling $\left[\mathrm{kW} / \mathrm{m}^{2}\right]$ in comparison with the power demand for the assumed spring days.

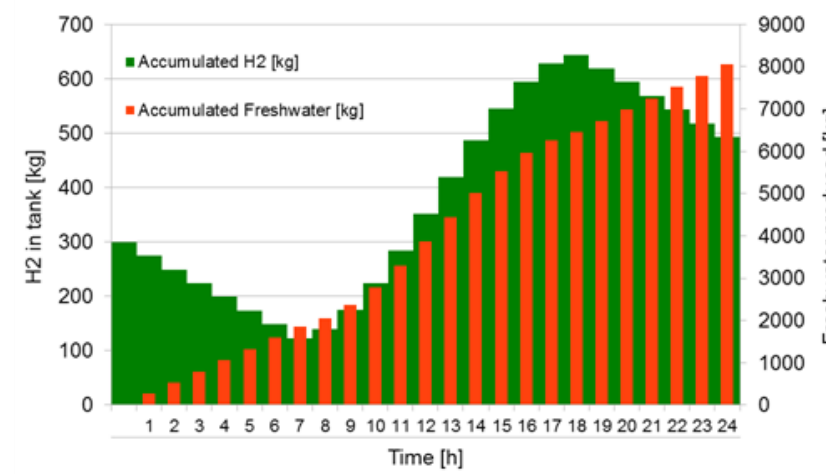

a) Day 1

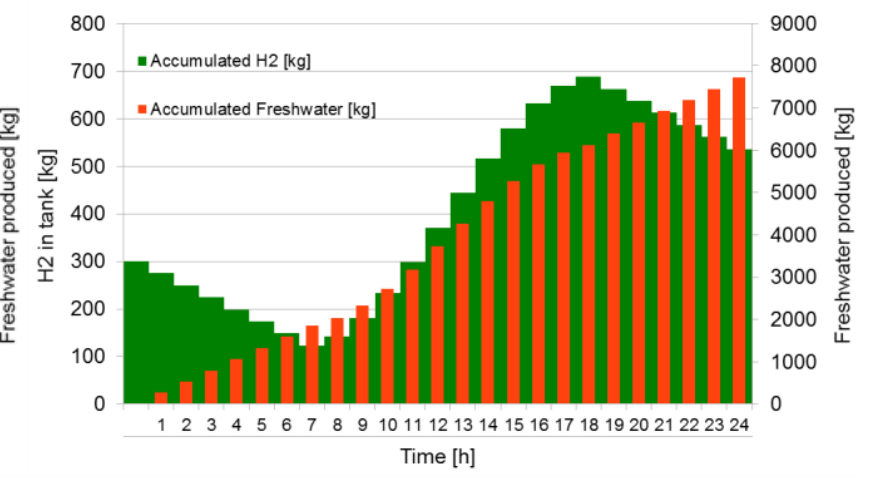

b) Day 2

Figure 10. Hydrogen and freshwater variation in the stock for the assumed spring days.

\subsection{Fall days}

Similar to the spring season two days are representing this season also, see Fig. 11. The peak solar radiations for these are 744 and $698 \mathrm{~kW} / \mathrm{m} 2$ for day 1 and 2, respectively. Similar to the spring season the radiation starts at 6 in the morning and ends at 20 in the evening. However, the dish-Stirlings do not start to deliver power from 8 in the morning to 18 in the afternoon, see Fig. 12. The accumulated hydrogen at the end of these two selected days are 493 and $449 \mathrm{~kg}$ respectively. With day 1 the hydrogen production increases by about $64 \%$ while this increase is about $50 \%$ with day 2 . Again, promising results which indicates the potential of such plant even for lower climate with lower solar radiation then average.

Freshwater production for day 1 is about $7400 \mathrm{~kg}$, while this value is about $7080 \mathrm{~kg}$ for the second day see Fig. 12. The plant suns on SOEC mode daytime (8 to 18) SOFC mode during night time (19 
to 7). Both hydrogen and freshwater productions are lower than the case for spring days. The reason lies on the assumption of lower radiation for fall days compared to the spring days.

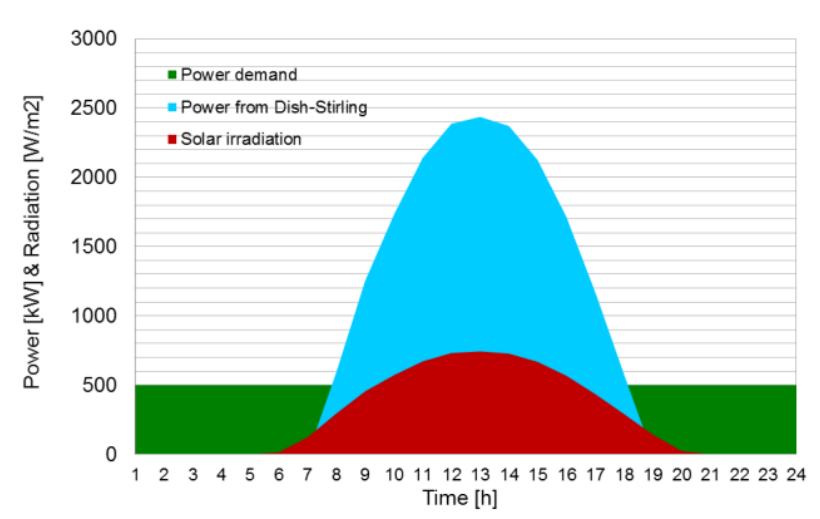

a) Day 1

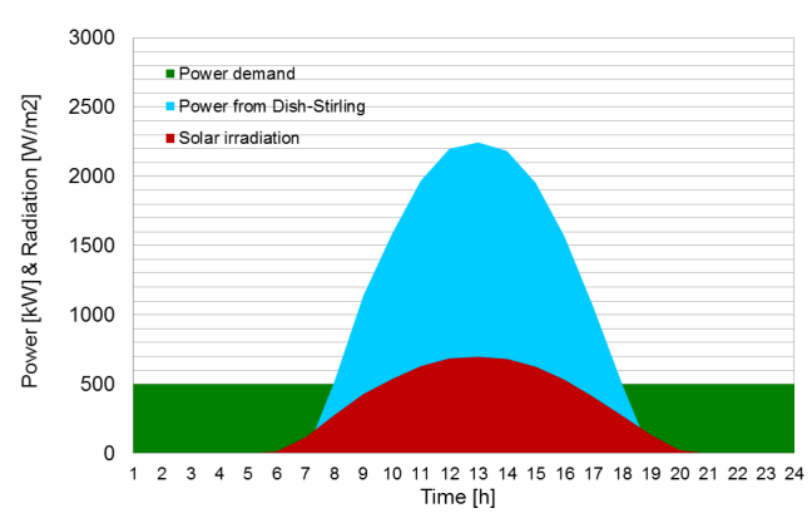

b) Day 2

Figure 11. Solar irradiance $\left[\mathrm{kW} / \mathrm{m}^{2}\right]$ and power produced from dish-Stirling $\left[\mathrm{kW} / \mathrm{m}^{2}\right]$ in comparison with the power demand for the assumed fall days.

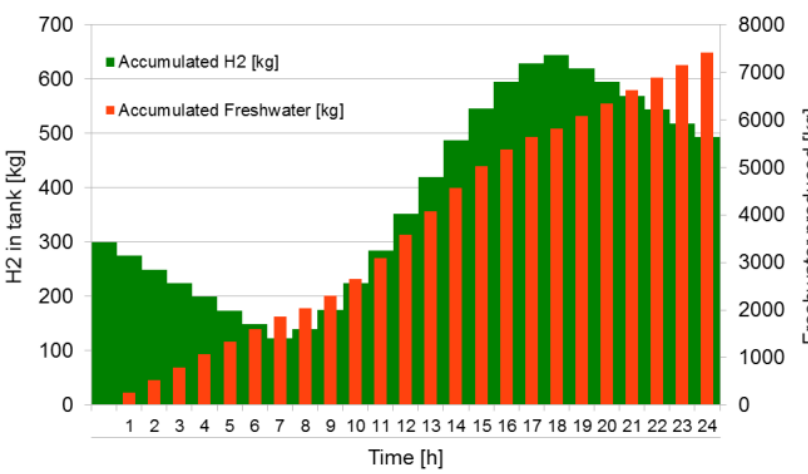

a) Day 1

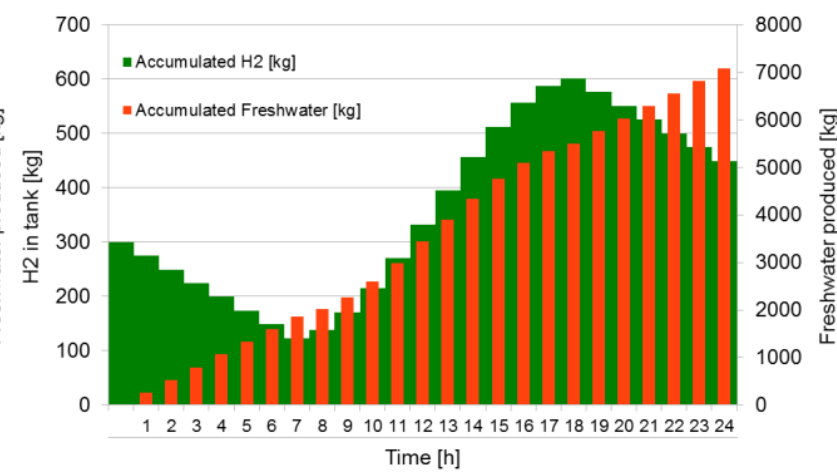

b) Day 2

Figure 12. Hydrogen and freshwater variation in the stock for the assumed fall days.

\subsection{Winter days}

Similar to the spring season two days are representing this season also, see Fig. 13. Again, the chosen second day has 5\% lower solar radiation indicating two different days with different irradiations. However, these two winter days have a peak radiation that is significantly lower when compared to the summer day. The peak irradiations are 651 and $604 \mathrm{~kW} / \mathrm{m}^{2}$ respectively. Again solar radiation starts from 6 in the morning and ends at 20 in the afternoon, but the SOEC mode does not start until 9 in the morning which is one hour later the previous cases. The SOEC modes last until 17 which is also one later than the previous cases. For these two winter days the SOEC mode start at 399 and 370 for the chosen days. Again, the demand power is $500 \mathrm{~kW}$ continuously all day long.

Hydrogen production starts at 9 in the morning and ends at 17 in the evening for both winter days, see Fig. 14. This is two hours lower when compared to the previous cases. Hydrogen production is only $376 \mathrm{~kg}$ for day 1 and $336 \mathrm{~kg}$ for day 2 . Also the amount of hydrogen production is considerably lower than the previous seasons. The interesting point is that the amount of hydrogen is still higher than $300 \mathrm{~kg}$ at the end of the day. This is tremendously exciting since the results indicate that if some days are very cloudy and the irradiation is thus much lower there exist some backup hydrogen to be used. However, one needs to simulate the plant against real data to discover the possibility of the using the plant during entire year. The primary results in this study are encouraging.

The freshwater production is about $6975 \mathrm{~kg}$ for day 1 and $6690 \mathrm{~kg}$ for day 2 of the winter. Although, the freshwater production is much lower than the summer season but is still very high to indicating the possibility of using such plant in the future. 

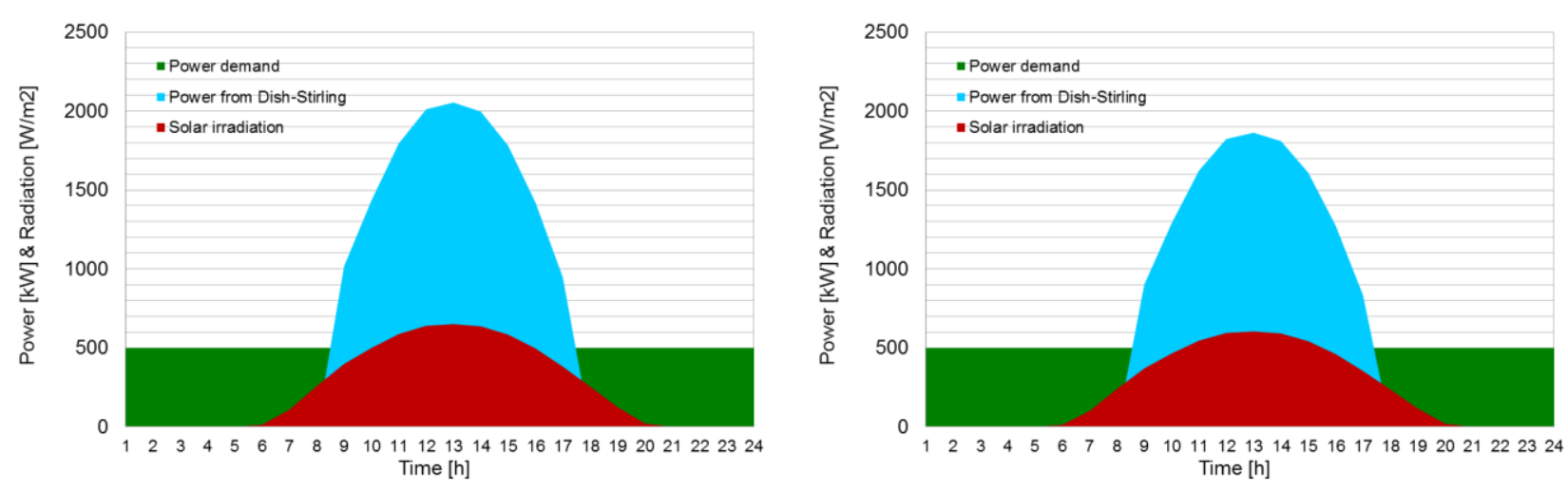

a) Day 1 b) Day 2

Figure 13. Solar irradiance $\left[\mathrm{kW} / \mathrm{m}^{2}\right]$ and power produced from dish-Stirling $\left[\mathrm{kW} / \mathrm{m}^{2}\right]$ in comparison with the power demand for the assumed winter days.

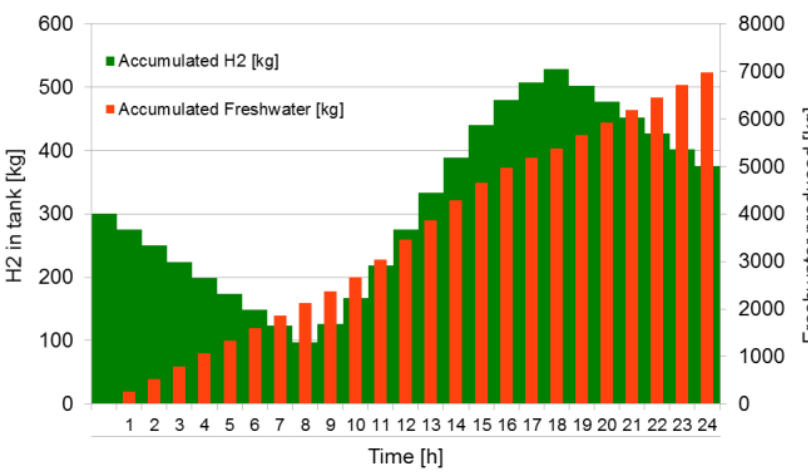

a) Day 1

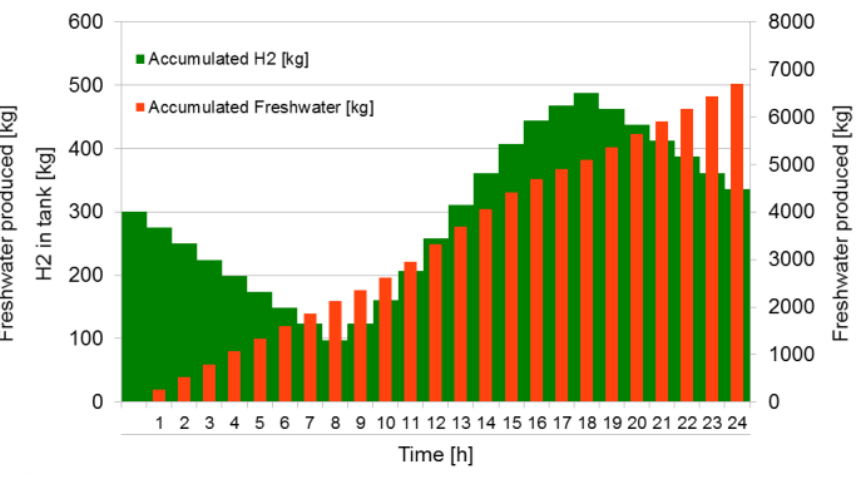

b) Day 2

Figure 14. Hydrogen and freshwater variation in the stock for the assumed winter days.

\subsection{Discussions}

The results obtained above are encouraging and indicate that detailed data for solar irradiation are needed to run the system on and evaluate plant performance. Such data shall also include cloudy days and other details that may affect the irradiation. However, the preliminary results show that such system can store renewable energies in fuel form and then use whenever needed. In this study, solar energy is stored but it also would be interesting to study wind energy also. Wind turbines can easily replace the dish-Stirling units to feed electricity for the system as well as cover the demand when wind is blowing. One can also combine wind turbines with dish units to cover the power demand and to run the electrolyzer.

\section{Conclusions}

A novel system is proposed to deliver electricity and freshwater from sun radiation at any time (day and night), even though there is no irradiation for a short period. The presented system uses a reversible solid oxide cells technology, dish-Stirling, parabolic trough solar collectors, and direct contact membrane distillations units.

The suggested plant is evaluated on a random days for Nordic European climate which has a duty to supply a constant demand of $500 \mathrm{~kW}, 24 \mathrm{~h}$ a day. The results indicate that, with a RSOC of 70 stacks with 200 cells, 175 units of $25 \mathrm{~kW}$ dish-Stirling and a $7 \times 250 \mathrm{~m}$ of PTSC, the plant was not only able to meet the constant demand but was also able to increase the accumulated hydrogen for all days considered. 
The present study consider one day in summer day and two days in spring, fall and winter. The accumulated hydrogen increased by $121 \%$ for the selected summer day, $93 \%$ and $77 \%$ for spring days, $64 \%$ and $50 \%$ for the fall days, $25 \%$ and $12 \%$ for the winter days.

The daily freshwater production is far more than 6500 liters per day during the year. Freshwater production is 8733 liters for the selected summer day, 8051 and 7722 liters for the spring days, 7407 and 7084 for the fall days, 6974 and 6691 liters for the winter days.

\section{Nomenclature}

\begin{tabular}{|c|c|}
\hline A & Area \\
\hline $\mathrm{AC}$ & Alternate Current \\
\hline $\mathrm{AP}$ & Anode preheater \\
\hline $\mathrm{C}$ & Compressor \\
\hline $\mathrm{CP}$ & Cathode preheater \\
\hline $\mathrm{Cp}$ & Heat capacity \\
\hline $\mathrm{C}_{\mathrm{R}}$ & Concentration ratio \\
\hline $\mathrm{D}, \mathrm{d}$ & Diameter \\
\hline DC & Direct Current \\
\hline DCMD & Direct Contact Membrane Distillation \\
\hline DNA & Dynamic Network Analysis \\
\hline DP & Relative pressure drops \\
\hline E & Voltage \\
\hline $\mathrm{EC}$ & Electrolyzer cell \\
\hline EES & Electrical Energy Storage \\
\hline$F$ & Faraday's constant : $96485.3365 \mathrm{C} / \mathrm{mol}$ \\
\hline FC & Fuel Cell \\
\hline$f_{\text {loss }}$ & loss factor \\
\hline$f_{s}$ & Friction coefficient \\
\hline$G$ & Gibbs energy \\
\hline$g$ & Universal gravity constant $: 9.81 \mathrm{~m} / \mathrm{s}^{2}$ \\
\hline$\dot{G}$ & Mass velocity \\
\hline$H$, eth & Enthalpy \\
\hline$h$ & Convection coefficient \\
\hline HTF & Heat transfer fluid \\
\hline HX & Heat Exchanger \\
\hline $\mathrm{H} 2$ & Hydrogen \\
\hline$i$ & Current \\
\hline $\mathrm{J}$ & Current density \\
\hline $\mathrm{k}$ & Conductivity \\
\hline$K_{\gamma \tau \alpha}$ & Incidence angle modifier \\
\hline $\mathrm{L}, 1$ & Length \\
\hline LEP & Liquid Entry Pressure \\
\hline LHV & Low heating value \\
\hline M & Molar mass \\
\hline MD & Membrane Distillation \\
\hline$\dot{m}$ & Mass flow \\
\hline $\mathrm{N}_{\text {cell }}$ & Number of cells per stack \\
\hline $\mathrm{N}_{\text {stack }}$ & Number of Stacks \\
\hline$\dot{N}$ & Molar flow \\
\hline $\mathrm{P}$ & Power \\
\hline $\mathrm{p}$ & pressure \\
\hline $\mathrm{P}^{0}$ & Partial pressure \\
\hline
\end{tabular}




$\begin{array}{ll}\text { PF } & \text { Feed pressure } \\ \text { PFm } & \text { Membrane pressure on the feed side } \\ \text { PP } & \text { Permeate pressure } \\ \text { PPm } & \text { Membrane pressure on the permeate side } \\ \text { Pr } & \text { Prandtl number } \\ \text { PTSC } & \text { Parabolic Trough Solar Collector } \\ \text { PTSC-SG } & \text { Parabolic Trough Solar Collector Steam Generator } \\ \text { PV } & \text { Photovoltaic } \\ \text { Q } & \text { Heat } \\ \text { R } & \text { Universal gas constant : 8.314 J/molK } \\ \text { Re } & \text { Reynold's number } \\ \text { RSOFC } & \text { Reversible Solid Oxide Fuel Cell } \\ \text { RSOC } & \text { Reversible Solid Oxide Cell } \\ \text { S } & \text { Direct sun radiation } \\ \text { S } & \text { Section } \\ \text { SOEC } & \text { Solid Oxide Electrolyze Cell } \\ \text { SOFC } & \text { Solid Oxide Fuel Cell } \\ \text { SWP } & \text { Sea water preheater } \\ \text { T } & \text { Thickness } \\ \text { T } & \text { Temperature } \\ \text { U } & \text { Heat transfer coefficient } \\ \text { Ucc } & \text { Combined heat loss transfer coefficient } \\ U F & \text { Utilization Factor } \\ x & \text { Vapor quality } \\ \text { v } & \text { Velocity, specific volume } \\ \text { w } & \text { Aperture } \\ & \end{array}$

\section{$\underline{\text { Greek letters }}$}

\section{$\Delta$}

$\Upsilon$

$\Omega$

$\alpha$

$\delta$

$\varepsilon$

$\epsilon$

$\phi$

$\gamma$

$\eta$

$\varphi$

$\lambda$

$\mu$

$\pi$

$\rho$

$\sigma$

$\tau$

$\xi$

$\psi$

$\zeta$

\section{Difference}

Heat capacity ratio

Molecular diameter of air

Absorptance

Absolute roughness

Porosity

Emissivity

Angle of incidence

Intercept factor

Efficiency

Specular reflectance

Mean free path

Dynamic viscosity

Pi : 3.1416

density

Stefan-Boltzmann constant : $5.678 \times 10^{-8} \mathrm{~W} / \mathrm{m}^{2} \mathrm{~K}^{4}$

Transmittance

Compression ratio

Surface tension

Gas temperature ratio

$\underline{\text { Subscripts }}$

absf

Absorbed by the fluid 


\begin{tabular}{ll} 
act & Activation \\
amb & Ambient \\
an & Anode \\
as & Anode limit \\
cath & Cathode \\
ci & Inner part of the cover \\
co & Outer part of the cover \\
conc & Concentration \\
cov & Cover \\
cs & Cathode limit \\
dens & Density \\
eff & Effective \\
el & Electrolyte \\
f & Feed side \\
fm & Fluid mean \\
G & Gas \\
gen & Generator \\
in & Inlet \\
L & Liquid, Loss \\
$\mathrm{m}$ & Membrane \\
ohm & Ohmic \\
opt & Optimal \\
out & Outlet \\
p & Permeate side \\
r & Reaction \\
rec & Receiver \\
ri & Inner part of the receiver \\
ro & Outer part of the receiver \\
ROM & Receiver Out (surface) Mean \\
s & Isentropic \\
supp & Support \\
w & Wind \\
Z & Segment number \\
& \\
\hline &
\end{tabular}

\section{References}

[1] Viviani M, Canu G, Carpanese MP, Barbucci A, Sanson A, Mercadelli E, Nicolella C, Vladikova D, Stoynov Z, Chesnaud A, Thorel A, Ilhan Z, Ansar SF. Dual cells with mixed protonic-anionic conductivity for reversible SOFC/SOEC operation. Energy Procedia 2012:182-189.

[2] Graves C, Ebbesen SD, Jensen SH, Simonsen SB, Mogensen MB. Eliminating degradation in solid oxide electrochemical cells by reversible operation. Nature Materials 2015;14(2):239244.

[3] Ni M, Leung MKH, Leung DYC. Technological development of hydrogen production by solid oxide electrolyzer cell (SOEC). Hydrogen Energy 2008:33;2337-54.

[4] Chen B, Xu H, Ni M. Modelling of SOEC-FT reactor: Pressure effects on methanation process. Applied Energy 2017:185;814-24.

[5] Dillig M, Leimert J, Karl J. Planar high temperature heat pipes for SOFC/SOEC stack applications. Fuel Cells 2014:14;479-488.

[6] Odeh SD and Morrison GL. Optimization of parabolic trough solar collector system. Energy Research 2006:30;259-271. 
[7] Coccia G, Latini G, Sotte M. Mathematical modeling of a prototype of parabolic through solar collector. Renewable and Sustainable Energy 2012:4 (023110):1-15.

[8] Li C, Wang RZ, Wang LW, Li TX, Chen Y. Experimental study on an adsorption icemaker driven by parabolic trough solar collector. Renewable Energy 2012:57;223-233.

[9] Bortolato M, Dugaria S, Del Col D. Experimental study of a parabolic trough solar collector with flat bar-and-plate absorber during direct steam generation. Energy 2016:116;1039-50.

[10] Akikur RK, Saidur R, Ping HW, Ullah KR. Performance analysis of a co-generation system using solar energy and SOFC technology. Energy Conversion and Management 2014:79;415430.

[11] Burgoyne A, Vahdati MM. Direct Contact Membrane Distillation. Desalination and Water Treatment 2000:35(8);1257-84.

[12] Shirazi MMA, Kargari A, Shirazi MJA. Direct contact membrane distillation for seawater desalination. Separation Science and Technology 2012:49;368-375.

[13] Suárez F, Ruskowitz JA, Tyler SW, Childress AE. Renewable water: Direct contact membrane distillation coupled with solar ponds. Applied Energy 2015:158;532-539.

[14] Nakoa K, Date A, Akbarzadeh A. DCMD modelling and experimental study using PTFE membrane. Desalination and Water Treatment 2016:57;3835-45.

[15] Cath TY, Adams VD, Childress AE. Experimental study of desalination using direct contact membrane distillation: a new approach to flux enhancement. Membrane Science 2003:228;516.

[16] Schmidt O, Gambhir A, Staffell I, Hawkes A, Nelson J, Few S. Future cost and performance of water electrolysis: An expert elicitation study. Hydrogen Energy 2017:30470-92.

[17] Rokni M. Thermodynamic analyses of municipal solid waste gasification plant integrated with solid oxide fuel cell and Stirling hybrid system. Hydrogen Energy 2015:40;7855-7869.

[18] Holtappels P, DeHaart LGJ, Stimming U, Vinke IC, Mogensen M. Reaction of CO/CO2 gas mixtures on Ni-YSZ cermet electrode. Applied Electrochemistry 1999;29:561-68.

[19] Matsuzaki Y Yasuda I. Electrochemical oxidation of $\mathrm{H} 2$ and $\mathrm{CO}$ in a H2-H2O-CO-CO2 system at the interface of a Ni-YSZ cermet electrode and YSZ electrolyte. Electrochemical Society 2000;147(5):1630-35.

[20] Keegan KM, Khaleel M, Chick LA, Recknagle K, Simner SP, Diebler J. Analysis of a planar solid oxide fuel cell based automotive auxiliary power unit, SAE Technical Paper Series 2002;No. 2002-01-0413.

[21] Zhu H, Kee RJ. A general mathematical model for analyzing the performance of fuel-cell membrane-electrode assemblies. Power Sources 2003;117:61-74.

[22] Costamagna P, Selimovic A, Del Borghi M, Agnew G. Electrochemical model of the integrated planar solid oxide fuel cell (IP-SOFC). Chemical Engineering Journal 2004;102(1):61-69.

[23] Christiansen N, Hansen JB, Holm-Larsen H, Linderoth S, Larsen PH, Hendriksen PV, Hagen A. Solid oxide fuel cell development at Topsoe fuel cell and Risø. Electrochemical Society 2007;7(1):31-38.

[24] Smith JM, Van Ness HC, Abbott MM. 2005. Introduction to Chemical Engineering Thermodynamics, 7th edition, Boston:McGraw-Hill.

[25] Winnick J. 1997. Chemical engineering thermodynamics. John Wiley \&Sons, New Yourk.

[26] Ni M, Leung KH, Leung DYC. Energy and exergy analysis of hydrogen production by solid oxide steam electrolyzer plant. Hydrogen Energy 2007:32;4648-4660.

[27] Hernández-Pacheco E, Singh D, Nutton PN, Patel N, Mann MD. A macro-level model for determining the performance characteristics of solid oxide fuel cells. J Power Sources 2004:138;174-186.

[28] Duffie JA and Beckman WA. Solar Engineering of Thermal Processes. $4^{\text {th }}$ Ed., John Wiley\& Sons, 2013, ISBN 978-1-118-41541-2 (ebk).

[29] Ni M, Leung KH, Leung DYC. A modeling study on concentration overpotentials of a reversible solid oxide fuel cell. J Power Sources 2006:163;460-466. 
1006

1007

1008

1009

1010

1011

1012

1013

1014

1015

1016

1017

1018

1019

1020

1021

1022

1023

1024

1025

1026

1027

1028

1029

1030

1031

1032

1033

1034

1035

1036

1037

1038

1039

1040

1041

1042

1043

1044

1045

1046

1047

1048

1049

1050

1051

1052

[30] Rokni M. Thermodynamic analysis of SOFC (solid oxide fuel cell)-Stirling hybrid plants using alternative fuels. Energy 2013:61;87-97.

[31] Stine WB and Diver RB. A Compendium of solar dish/Stirling technology. 1994. Available form US DOE under contract Nr. 67-3678, Report Nr. SAND93-7026 UC-236.

[32] Odeh SD, Morrison GL and Behnia M. Modeling of parabolic trough direct steam generation solar collectors. Solar Energy 1998:62;395-406.

[33] Gungor KE, Winteron RHS. A general correlation for flow boiling in tubes and annuli. Int. J. Heat Mass Transfer 1986:29(3);351-358.

[34] Hammad M, Al-Qtiemat A, and Alshqirate A. Modeling and Analysis of the Performance of a Parabolic Trough Solar Concentrator System. ASME International Mechanical Engineering Congress and Exposition, IMECE 2013-63411, Nov. 15-21, San Diego, USA 2013. DOI 10.1115/IMECE2013-63411.

[35] Thome JR. Two-Phase pressure drops inside tubes. in Databook III. Laboratory of Heat and Mass Transfer, Swiss Federal Institute of Technology Lausanne, Switzerland. http://ltcm.epfl.ch

[36] Incropera FP, DeWitt DP, Bergman TL and Lavine AS. Introduction to Heat Transfer. 5th ed, Wiley 2006, ISBN 978-0471457275.

[37] Nellis G, Klein S. Heat Transfer. Cambridge 2009, ISBN 978-0-521-88107-4.

[38] Rohsenow WM, Hartnett JP, Cho YI. Handbook of heat transfer, 3rd ed. McGraw-Hill 1998. ISBN 0-07-053555-8.

[39] Poling BE, Prausnitz JM and O'Connell JP. The Properties of Gases and Liquids.: $5^{\text {th }}$ Ed., McGraw-Hill, 2004, Digital version available.

[40] Kim YD, Thu K, Ghaffour N, Ng KC. Performance investigation of a solar-assisted direct contact membrane. Membrane Science 2013:427:345-364.

[41] AlZahrani AA and Dincer I. Thermodynamic and electrochemical analyses of a solid oxide electrolyzer for hydrogen production. Hydrogen Energy 2017:21404-23.

[42] Jensen SH, Sun X, Ebbesen SD, Knibbe R, Mogensen M. Hydrogen and synthetic fuel production using pressurized solid oxide electrolysis cells. Hydrogen Energy 2010:9544-49.

[43] Elmegaard B. Simulation of Boiler Dynamics - development, evaluation and application of a general energy system simulation tool. PhD. Thesis 1999, Technical University of Denmark, Report Nr: ET-PhD 99-02. ISBN 87-7475-222-7.

[44] Cheng LH, Wu PC, Chen J. Modeling and optimization of hollow fiber DCMD module for desalination. J Membrane Science 2008;318:154-166.

[45] Qu M, Archer DH, Masson SV. A linear parabolic trough solar collector performance model. Renewable Energy Resources and a Greener Future 2006;VIII-3-3: ESL-IC-06-11-267. Online available. Assessed January 2018.

[46] Yaqi L, Yaling H, Weiwei W. Optimization of solar-powered Stirling heat engine with finitetime-thermodynamics. Renewable Energy 2011;36:421-427.

[47] Š́ri M, Remund J, Cebecauer T, Hoyer-Klick C, Dumortier D, Huld T, Stackhouse PW Jr, Ineichen P. 2009. Comparison of Direct Normal Irradiation Maps for Europe. SolarPACES Conference (Concentrated Solar Power and Chemical Energy Systems), 15 -18 Sep. 2009, Berlin, Germany.

[48] Š́ri M, Huld TA, Dunlop ED. PV-GIS: a web-based solar radiation database for the calculation of PV potential in Europe. Sustainable Energy 2005;24(2):55-67.

[49] Ciolkosz D. SASRAD: An hourly-timestep solar radiation database for South Africa. J. Energy in Southern Africa 2009:20(1);25-34. 